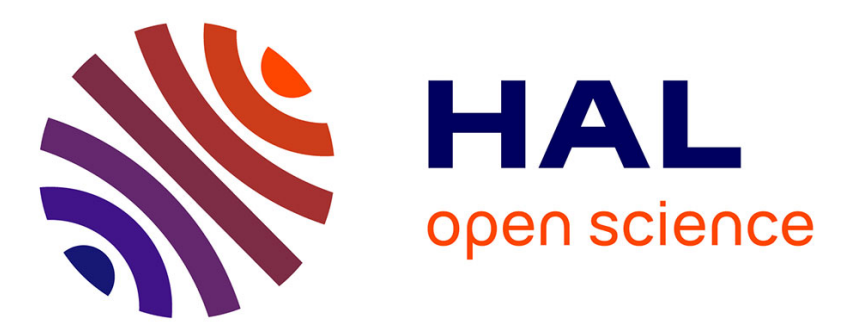

\title{
Functional agrobiodiversity and agroecosystem services in sustainable wheat production. A review
}

\author{
Ambrogio Costanzo, Paolo Bàrberi
}

\section{To cite this version:}

Ambrogio Costanzo, Paolo Bàrberi. Functional agrobiodiversity and agroecosystem services in sustainable wheat production. A review. Agronomy for Sustainable Development, 2014, 34 (2), pp.327-348. 10.1007/s13593-013-0178-1 . hal-01234799

\section{HAL Id: hal-01234799 \\ https://hal.science/hal-01234799}

Submitted on 27 Nov 2015

HAL is a multi-disciplinary open access archive for the deposit and dissemination of scientific research documents, whether they are published or not. The documents may come from teaching and research institutions in France or abroad, or from public or private research centers.
L'archive ouverte pluridisciplinaire HAL, est destinée au dépôt et à la diffusion de documents scientifiques de niveau recherche, publiés ou non, émanant des établissements d'enseignement et de recherche français ou étrangers, des laboratoires publics ou privés. 


\title{
Functional agrobiodiversity and agroecosystem services in sustainable wheat production. A review
}

\author{
Ambrogio Costanzo • Paolo Bàrberi
}

Accepted: 6 September 2013 / Published online: 27 September 2013

(C) INRA and Springer-Verlag France 2013

\begin{abstract}
Agrobiodiversity can improve the sustainability of cropping systems in a context of low external inputs and unpredictable climate change. Agrobiodiversity strategies to grow wheat are breeding ad hoc cultivars for organic and lowinput systems, wheat-legume intercrops and living mulches, cultivar mixtures, and the use of genetically heterogeneous populations. However, applying those strategies can fail due the lack of a well-focused framework. Therefore, we need a better integration between breeding and management and a clear focus on crop traits related to key agroecosystem services. Here, we review the use of agrobiodiversity in wheat production, focusing on breeding and management. We discuss five agroecosystem services: (1) weed reduction, (2) nitrogen use efficiency, (3) abiotic stress tolerance, (4) disease and pest reduction and (5) yield and yield stability. We categorise agrobiodiversity into functional identity, functional composition, and functional diversity, in order to link crop traits to agroecosystem services. Linking crop traits to agroecosystem services could in turn lead to concrete options for farmers and policy. We discuss the relations between crop identity and crop heterogeneity. We also discuss the partitioning of crop heterogeneity between functional composition and functional diversity.
\end{abstract}

Keywords Agroecosystem service $\cdot$ Breeding $\cdot$ Composite cross population $\cdot$ Cultivar mixture $\cdot$ Evolutionary breeding . Intercropping $\cdot$ Living mulch $\cdot$ Low input · Organic farming · Trait

\footnotetext{
A. Costanzo $\cdot$ P. Bàrberi $(\square)$

Institute of Life Sciences, Scuola Superiore Sant'Anna, Piazza Martiri della Libertà 33, 56127 Pisa, PI, Italy

e-mail: barberi@sssup.it
}

Contents

1. Introduction

2. State-of-the-art strategies for using agrobiodiversity in sustainable wheat production

3. Planned agrobiodiversity for key agroecosystem services

3.1. Methodology

3.2. Weed reduction

3.3. Nitrogen use efficiency

3.4. Abiotic stress tolerance

3.5. Disease and pest reduction

3.6. Yield and yield stability

4. Planned agrobiodiversity: functional categories and related strategies

4.1. Three functional categories to address agrobiodiversity

4.2. Relations between crop identity and crop heterogeneity

4.2.1. Identity and heterogeneity of the crop stand

4.2.2. Identity and heterogeneity of the seeds

4.3. Functional composition and functional diversity of the crop stand

4.3.1. Functional composition in species and cultivar mixtures

4.3.2. Functional genetic diversity in a dynamic perspective

5. Discussion

6. Conclusion

\section{Introduction}

Common wheat (Tiriticum aestivum L.) and durum wheat (Triticum durum Desf. or Triticum turgidum L. subsp. durum) are the leading crops for human nutrition in Europe and in most temperate regions worldwide, and as such, they are facing the challenge of being produced more sustainably, with reduced levels of external inputs. An increasing body of 
literature addresses cropping system diversification as an innovation pathway to improve wheat production, especially in the perspective of organic and low external input systems, of production in marginal areas and of adaptation to climate change. However, the efficacy of diversity-based innovation and policy may suffer from the lack of a well-focused approach, resulting in only partial exploitation of the functional role of agricultural biodiversity (hereafter 'agrobiodiversity') (Moonen and Bàrberi 2008) in enhancing the provision of agroecosystem services, intended as 'the benefits provided by ecosystems to humans' (Millennium Ecosystem Assessment 2003).

How can a wheat crop be made more functional in providing the agroecosystem services expected by farmers? Farmers have complex objectives while planning a cropping cycle, e.g. reducing production costs, minimising risk of crop failure or preventing yield and quality reduction. In this respect, the choice of which cultivar to grow is crucial, especially in the case of organic or low-input farming systems. Agricultural research and extension services generally support farmers in this decision-making by providing lists of recommended cultivars updated yearly and certified through Value for Cultivation and Use (VCU) and Distinctness, Uniformity and Stability (DUS) protocols (Foletto 2008; Jones et al. 2003). However, these protocols are often unable to provide adequate solutions in terms of cereal cultivars adapted to organic conditions (Wolfe et al. 2008), although the VCU protocol can be adjusted to meet these needs (Osman et al. 2008). Indeed, reduction in the use of external inputs increases uncertainty in crop performance, due to stronger effect of the genotype-by-environment interaction (Desclaux et al. 2008). Current challenges posed by climate change exacerbate such uncertainty and urge the need to develop different approaches and tools for variety selection and crop management (Fig. 1) (Ceccarelli et al. 2010; Powell et al. 2012; Reidsma et al. 2010).

The potential of agrobiodiversity to support agriculture (Duelli 2006) is nowadays a key concept, yet still too broad and fuzzy to be concretely useful for farmers. So far, the search for better cultivars for organic and low external input systems has mainly been approached through alternative breeding models such as selection for target environments and participatory cultivar selection (Almekinders and Elings 2001; Lammerts van Bueren et al. 2011). However, to fully exploit the potential of agrobiodiversity to improve cropping systems, it is important to further widen the range of approaches and solutions. This would only be possible by focusing on traits that are clearly related to target agroecosystem services and by integrating breeding with management.

The aim of this paper is to show that a trait-based functional categorization of agrobiodiversity can better highlight those approaches and solutions that are more likely to improve the sustainability of wheat production.

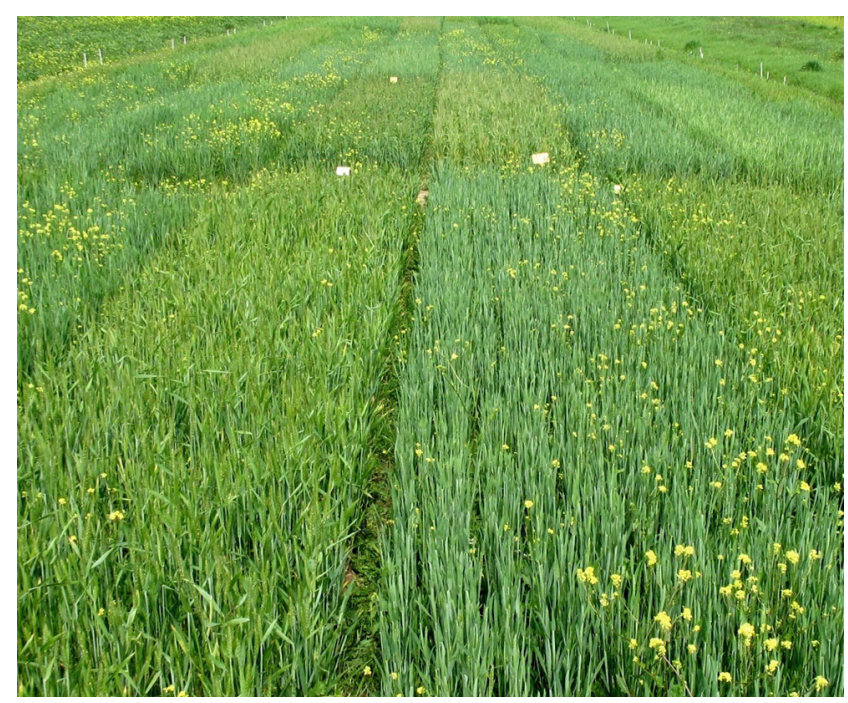

Fig. 1 Cultivar evaluation trials embedded in organic and low-input cropping systems: the first step to improve organic and low-input wheat growing. Photo: A. Costanzo

\section{State-of-the-art strategies for using agrobiodiversity in wheat production}

Besides the classical distinction between genetic, species and habitat levels (Parris 2001), agrobiodiversity can also be classified between 'planned' and 'associated'. The first represents the elements (within each level) that are deliberately introduced in agroecosystems by humans (Vandermeer et al. 2002), while the second includes those elements that are present in the agroecosystem without being introduced (e.g. wild flora and fauna). However, the overlap between these two classifications is not fully agreed. Parris (2001) proposed a set of indicators in which the genetic level of agrobiodiversity is only relevant for the planned component and the species level only for the associated component, while Wetterich (2001) considers important the species level also for the planned component. Moreover, the genetic level of planned agrobiodiversity may refer to either 'different' cultivars (genetic divergence between cultivars) or 'diverse' cultivars (genetic heterogeneity within a cultivar) (Brown and Hodgkin 2007; Cox and Wood 1999). Furthermore, the use of planned agrobiodiversity is addressed both by widening the range of choice for cultivars, e.g. through appropriate germplasm management, conservation and exploitation (Able et al. 2007), and by exploring the potential of increased canopy heterogeneity in enhancing ecosystem services (Newton et al. 2009).

A huge body of literature has addressed agrobiodiversity use in breeding. Here, the aim is to exploit the variation of wheat germplasm to create cultivars able to enhance the provision of given agroecosystem services. Reviews by Witcombe et al. (2008) and McIntosh (1998) have exhaustively addressed the relationship between genetic diversity 
and abiotic stress tolerance or biotic stress resistance, while Able et al. (2007) reviewed the approaches to explore, capture and manipulate cereal germplasm diversity.

Besides being used in breeding, agrobiodiversity can also be used in crop management. Here, the aim is to enhance the provision of agroecosystem services by exploiting the advantages of heterogeneous instead of homogeneous crops (Marshall 1977). Hence, agrobiodiversity is not considered as a pool to pick useful genes from, but as an ecologically functional resource (Newton et al. 2009). Crop heterogeneity is mainly addressed through cultivar mixtures (Finckh et al. 2000), use of genetically heterogeneous populations (Phillips and Wolfe 2005) or species mixtures (Malézieux et al. 2009).

At the genetic level, as summarised by Döring et al. (2011), diversity may be deployed according to two distinct, but not self-excluding strategies:

1. Constituting cultivar mixtures by physically mixing seeds of available cultivars: This type of diversity has been proven to increase crop yield mainly through disease reduction (Cowger and Weisz 2008; Garret et al. 2009; Mundt 2002a). It must be noticed that this approach does not exclude the increase of diversity also at the species level, obtained by mixing seeds of different cereal species, like in the Eastern African mixture of wheat and barley (Hordeum vulgare L.) called 'hanfets' (Woldeamlak et al. 2008).

2. Reproducing seeds of bulk hybrid populations constituted by crossing a certain number of parental cultivars, resulting in a much greater genotypic diversity than cultivar mixtures, as in the case of composite cross populations: this approach, known as 'evolutionary breeding', started by Suneson (1956), demonstrated that grain yield could be increased by cultivating cereal bulk populations for several successive generations, thus exposing them to natural selection. The use and breeding of composite cross populations have recently gained interest, to meet the challenges posed by low external input and organic agriculture (Phillips and Wolfe 2005) and by climate change and environmental unpredictability (Ceccarelli et al. 2010).

At the species level, crop species mixtures in arable systems mainly refer to intercropping (Lithourgidis et al. 2011a). In the case of wheat, either true intercrops (mainly with grain legume crops) or living mulch systems (mainly with forage legumes) can be used. Here, the target services are mainly yield (attainable through increased land equivalent ratio; Banik 1996), nitrogen use efficiency (Stern 1993) and weed reduction (Liebman and Dyck 1993; Poggio 2005).

Although they share the common goal of cropping system diversification, these different strategies rely on a plurality of hypotheses linking agrobiodiversity to agroecosystem functioning (Fig. 2). As an example, maintaining highly diverse breeding populations is expected to provide more opportunities to create useful cultivars and, thus, to meet unpredictable needs through wider cultivar choice. On the other hand, growing a genetically diverse composite cross population is expected to buffer against climate unpredictability, thanks to its intrinsic heterogeneity. Differently, a cereal-legume intercrop is expected to improve nitrogen cycling, compared to a cereal monocrop, due to the co-presence of cereal and legume species, rather than to mere increased diversity. Therefore, a more focused framework is required to clarify the potential functional role of agrobiodiversity. To address this need, we will (a) explore the role of different strategies in enhancing agroecosystem functioning according to five key agroecosystem services and (b) cluster these different strategies under functional categories, representative of the key (agro)ecological mechanisms that can link agrobiodiversity to improved agroecosystem functioning.

\section{Planned agrobiodiversity for key agroecosystem services}

\subsection{Methodology}

Many studies, although not explicitly addressing biodiversity, can be interpreted in a 'biodiversity-for-agriculture' perspective (Bàrberi et al. 2010). In our literature search, we took into account experimental and review papers which (a) focused on genetic agrobiodiversity through a breeding approach and (b) focused on a diversification management strategy and tested if a positive relationship between that strategy and a given agroecosystem service exists. The literature search was performed on Scopus ${ }^{\circledR}$, Science Direct ${ }^{\circledR}$ and ISI Web of Science ${ }^{\circledR}$ databases without specifying temporal limitations. We crossed two series of keywords: the first related to agroecosystem services and the second to diversity-based strategies or tactics. As a common keyword representing the wheat crop we mainly used 'wheat', although we have also included key papers on barley and other winter cereals.

The first series of keywords was developed around five key services, namely (a) weed reduction, (b) nitrogen use efficiency, (c) abiotic stress reduction, (d) biotic stress reduction, and (e) yield, and represented different lexical expressions, as follows:

- 'weed reduction' AND/OR 'weed suppressive ability' AND/OR 'weed tolerance'

- 'nitrogen use efficiency'

- 'abiotic stress*'

- 'pest* reduction' AND/OR 'pest resistance' AND/OR 'pest* management'

- 'disease* AND/OR parasite* reduction' AND/OR 'disease* AND/OR parasite* resistance'; AND/OR 'disease* AND/OR parasite* management'

- 'yield'

The second series of keywords was developed around state-of-the-art diversification strategies or tactics, namely 
Fig. 2 Strategies for improving sustainable wheat production through agrobiodiversity use. 1 Common wheat (Triticum aestivum) old Italian cultivars (left) and modern commercial cultivars (right). 2 Detail of a common wheat composite cross population. 3 Intercropping of common wheat and field pea (Pisum sativum). Photos:

A. Costanzo

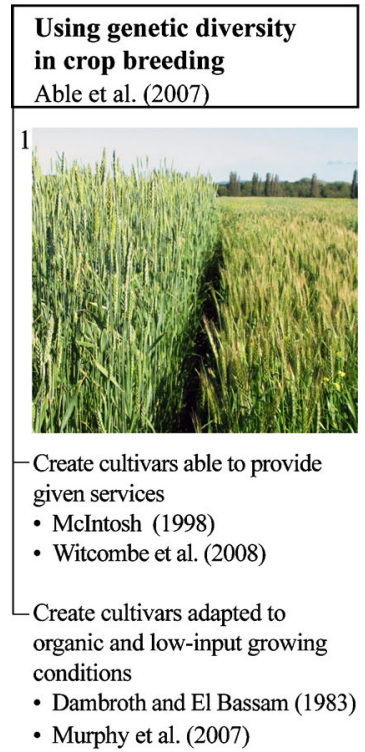

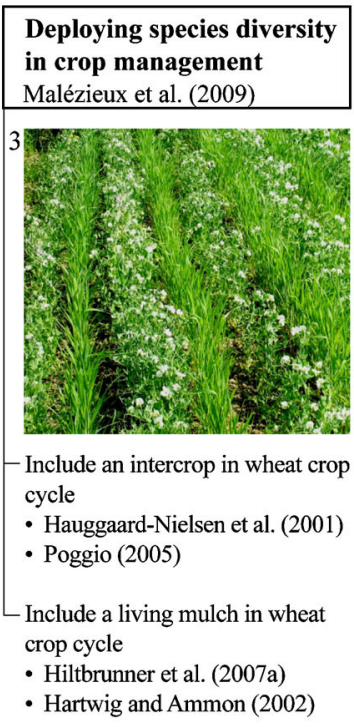

(a) the domain of plant genetic resource use in breeding, (b) intercropping, (c) mixing cultivars and (d) cultivating and reproducing heterogeneous populations:

- ('genetic diversity' AND/OR 'agrobiodiversity' AND/ OR 'agricultural biodiversity' AND/OR 'agricultural diversity') AND 'breeding'

- 'intercrop*' AND/OR 'liv* mulch*' AND/OR 'mixed crop*'

- 'variet* mixture*' AND/OR 'variet* blend' AND/OR 'cultivar mixture*' AND/OR 'cultivar blend*'

- 'heterogeneous population*' AND/OR 'bulk population' AND/OR 'composite cross

\subsection{Weed reduction}

Weed control is one of the most important challenges in organic and low-input wheat production, where it should be addressed by a systemic approach (Bàrberi 2002). A growing body of literature deals with the direct role of crops for weed reduction, in its three main facets: (a) reduce weed growth and abundance through crop interference mechanisms (Jordan 1993), (b) reduce yield losses caused by weeds through crop tolerance mechanisms (Callaway 1992) and (c) prevent invasions of alien or most aggressive weed species (Pollnac et al. 2009). How can a wheat crop better withstand and reduce weed competition?

Wheat cultivars vary in their ability to withstand competition from weeds. This variation is partly due to their weed suppressive ability and partly to their weed tolerance, i.e. their ability to interfere with weeds and their response to weed interference, respectively (Jordan 1993), which depend on several traits (Bertholdsson 2011; Callaway 1992; Cosser et al. 1997; Olesen et al. 2004). Early vigour, measured as early season crop biomass accumulation, and allelopathy have been referred to as the most important traits conferring weed tolerance (Huel and Hucl 1996). A set of morphological traits related to enhanced weed suppressive ability, e.g. earliest flag leaf emergence and anthesis, larger flag leaf surface, early crop height and cover and tiller number, has been linkage mapped and correlated to quantitative trait loci (QTL) (Coleman et al. 2001). The same approach has also been proposed for the production of allelochemicals in cereal crops (Belz 2007), especially in rice (Oryza sativa L.) (Zhou et al. 2008). This may enable the potential for marker-assisted selection (Lammerts van Bueren et al. 2010) and breeding for enhanced weed suppressive ability.

Crop species diversity is reported as a powerful tool for weed management (Hartwig and Ammon 2002), especially by associating cereal and legume species in intercropping (Lithourgidis et al. 2011a) or in living mulch systems (Hiltbrunner et al. 2007a). Field experiments showed that the weed suppressive ability of intercrops of barley and pea (Pisum sativum L.) grown in an additive design was higher and more stable across years and locations than in sole crops, due to the reduction of total weed biomass, weed species richness and relative abundance of dominant weeds (Poggio 2005). Hiltbrunner et al. (2007a) positively related the weed suppressive ability of legume species, included as living mulch in wheat, to their biomass production. However, living mulch systems were found to suppress mainly dicotyledonous weeds, thus favoring monocotyledonous weeds like Poa trivialis L. (Hiltbrunner et al. 2007b).

Overall, the main common evidence emerging from these experiments is the strong effect of interactions. For example, grain yield variation was almost fully ( $81 \%$ ) explained by genotype-by-environment interaction in a multi-site experiment comparing 12 winter wheat cultivars for their suppressive ability against Lolium rigidum Gaud. in Australia (Lemerle et al. 2001). Similarly, cultivar tolerance against the same weed had been 
proven to vary considerably between years and locations, making it unlikely to identify a 'best tolerant cultivar' (Cousens and Mokhtari 1998). Experiments conducted in Great Britain showed that advantage in weed tolerance of an old tall wheat cultivar over semi-dwarf modern cultivars vanished when sowing was delayed from mid-September to mid-October, resulting in lower early weed burden (Cosser et al. 1997). In intercropping and living mulch systems, wheat performance is highly linked to competitive relationships between wheat and the companion crop (Den Hollander 2012; Hiltbrunner et al. 2007a). To maximise weed control while minimising side effects, focus must be set on interaction factors such as sowing design (Thorsted et al. 2006a), mechanical regulation of the living mulch (Thorsted et al. 2006b), sowing densities (Hiltbrunner et al. 2007c), and wheat cultivar performance in a living mulch system (Hiltbrunner and Liedgens 2008).

In summary, it is possible to find, and efficiently plan and deploy, key traits that improve the weed reduction service in a context of predictable variability and in narrowly targeted areas. This information is potentially useful to target cultivar choice, intercropping/living mulch planning and breeding programmes (Hoad et al. 2012). However, it still remains unclear how to ensure short-term weed reduction when considering unpredictability, especially the climatic one. This can affect weed-crop interactions by influencing the sowing date and related issues, e.g. soil trafficability and the possibility to apply the false seedbed technique (Rasmussen 2004).

\subsection{Nitrogen use efficiency}

Nitrogen $(\mathrm{N})$ is amongst the main limiting factors for wheat production (Raun and Johnson 1999), especially under lowinput and organic conditions. After the diffusion of dwarf, high-input responsive cultivars (Yapa 1993), grain yield increased in parallel with nitrogen supply (Austin 1999), often leading to excess $\mathrm{N}$ use with negative environmental side effects (Davies and Sylvester-Bradley 1995). A major challenge nowadays is thus to maintain grain yield and quality with reduced $\mathrm{N}$ input. Therefore, the target is to increase $\mathrm{N}$ use efficiency, intended as a combination of (a) $\mathrm{N}$ uptake efficiency, i.e. total plant $\mathrm{N} /$ soil available $\mathrm{N}$, and (b) $\mathrm{N}$ translocation efficiency, i.e. grain yield/total plant $\mathrm{N}$ (Barraclough et al. 2010; Foulkes et al. 2009; Witcombe et al. 2008). According to Raun and Johnson (1999, worldwide cereal N use efficiency does not exceed $33 \%$. Systems not relying on chemical fertilisers usually suffer from the mismatch between wheat $\mathrm{N}$ requirements and $\mathrm{N}$ release from organic matter and fertilisers (Mäder et al. 2002; Pang and Letey 2000). How can a wheat crop be made more efficient in nitrogen use?

Many studies have been exploring the morpho-physiological traits linked with increased $\mathrm{N}$ use efficiency in wheat. As summarised by Foulkes et al. (2009), these traits are related to four strategies aimed at optimising the whole $\mathrm{N}$ use of wheat: from (a) optimised $\mathrm{N}$ capture and (b) nitrate assimilation, through, e.g. deeper root distribution and optimised activity of key enzymes, (c) maximised photosynthetic capacity and (d) improved $\mathrm{N}$ remobilization through $\mathrm{N}$ distribution in the canopy and optimised grain protein content. To obtain faster improvement, however, the impact of genotype-by-N interaction should be taken into account through appropriate tests (SylvesterBradley and Kindred 2009). Baresel et al. (2008) identified genotypic variation in $\mathrm{N}$ uptake among six common wheat cultivars tested in four locations in southern Germany and showed that higher $\mathrm{N}$ uptake during grain filling can favour wheat performance in environments with higher $\mathrm{N}$ availability, while early $\mathrm{N}$ uptake can be more important in N-limiting environments. Wheat selection for target environments appears thus as a potentially useful approach to enhance $\mathrm{N}$ use efficiency. QTL analysis of $\mathrm{N}$ use efficiency and genotype-by-N interaction for grain yield, grain protein yield and their components is opening the option for marker-assisted selection (Agrama 2006). Associations between QTL related to tolerance to low $\mathrm{N}$ and phenotypic markers such as awnedness, dwarfness and photoperiod-sensitivity have also been found (Laperche et al. 2007). A further major challenge in breeding for enhanced $N$ use efficiency is to improve screening methods for rhizosphererelated traits and the understanding of plant-soil-microbe relationships (Messmer et al. 2012).

As to management, many studies have focused on the impact of species association on wheat $\mathrm{N}$ uptake to enhance cereal yield and grain $\mathrm{N}$ content in low $\mathrm{N}$ environments (Bedoussac and Justes 2009). Growing wheat with a legume companion crop can increase wheat $\mathrm{N}$ uptake mainly due to reduced competition for $\mathrm{N}$ (Jensen 1996) rather than to direct $\mathrm{N}$ transfer from the legume to the cereal, which did not exceed $2.5 \%$ of total barley $\mathrm{N}$ uptake in a red clover (Trifolium pratense L.) barley intercrop (Baddeley et al. 2006). However, direct N transfer may be significantly enhanced by associated soil biota, like arbuscular mycorrhizal fungi (Johansen and Jensen 1996) and earthworms (Schmidt and Curry 1999). In turn, earthworm activity can be favoured by the co-presence of cereals and legumes (Schmidt et al. 2003). Obviously, N use complementarity in intercrops is also influenced by weed abundance and composition (Hauggaard-Nielsen et al. 2001).

Positive effects of legume living mulches on $\mathrm{N}$ cycling can be further enhanced by appropriate crop management. Manipulation of co-presence time, aimed at minimising cereal-legume competition, can optimise the efficiency of intercropping. Systems of temporary wheat and faba bean (Vicia faba L. var. minor Beck.) intercropping, with contemporary sowing and soil incorporation of the legume in early spring, have been shown to increase wheat protein content by 15 to $20 \%$ compared to wheat sole crop (Tosti and Guiducci 2010). Thorsted et al. (2006b) showed that the use of a brush weeder on white clover (Trifolium repens L.) bands to 
diminish legume competition in a clover-wheat intercrop increased wheat grain $\mathrm{N}$ content by $31 \%$ compared to unmanaged clover, especially when passed at flag leaf emergence. Brushing before flag leaf emergence resulted instead in maximum wheat yield increase.

A further challenge for better $\mathrm{N}$ use efficiency, especially under high precipitation levels, is to reduce $\mathrm{N}$ leaching in the autumn. Here, farmers can either sow winter wheat or spring wheat preceded by a late summer sown catch crop (ThorupKristensen et al. 2003). The inclusion of $\mathrm{N}_{2}$-fixing, non- $\mathrm{N}_{2}$ fixing and mixtures of $\mathrm{N}_{2}$-fixing and non $\mathrm{N}_{2}$-fixing catch crops in organic cropping systems was studied in Denmark by Doltra and Olesen (2013), with spring oats and spring barley as target cash crops. Yields of target crops were improved by the catch crop, but the effect size was dependent on target cereal and catch crops. Ryegrass, white and red clover mixture was proposed as the best strategy to reduce $\mathrm{N}$ leaching and improve yield in spring oat, but advantages on spring barley seemed to be more dependent on longer term effects. Thorup-Kristensen et al. (2009) highlighted the previously underestimated efficiency of winter wheat root system in reducing $\mathrm{N}$ losses. Being winter wheat able to yield more than spring wheat, it might be preferably grown in environments where $\mathrm{N}$ leaching is limited. Where $\mathrm{N}$ leaching is more severe, sowing a catch crop like rye (Secale cereale L.) or vetch (Vicia sativa L.), incorporated in the soil before sowing spring wheat, would more effectively reduce $\mathrm{N}$ leaching and increase $\mathrm{N}$ availability for the subsequent crop. Instead, in winter wheat, yield and grain protein content were improved by a catch crop composed of ryegrass (Lolium perenne L.) and a mixture of clover species undersown in preceding spring barley (Olesen et al. 2009). This experiment also showed that the catch crop was more effective than manure application in improving $\mathrm{N}$ use efficiency.

The complexity of $\mathrm{N}$ dynamics in organic and low-input cropping systems makes it difficult to identify general phenotypic traits and/or standard management options to improve $\mathrm{N}$ use efficiency. On the other hand, appropriate phenotypes can be identified and matched with appropriate management systems in a target environment.

\subsection{Abiotic stress tolerance}

Successful production under stress conditions is an important objective for organic and low-input cropping systems, where reduction of external inputs exacerbates the effects of environmental variation over time and space. Production under stress conditions should be based on crop local adaptation: this is the purpose of decentralised, locally based breeding programmes (Atlin et al. 2000; Ceccarelli 1989), which have been proven successful in marginal conditions (Ceccarelli 1994, 1996).

Many efforts have been done to identify and develop stresstolerant germplasm (Witcombe et al. 2008) and to explore the mechanisms of stress tolerance at the genomic level, e.g. drought tolerance in barley (Comadran et al. 2008), wheat and rice (Praba et al. 2009). Genetic variability for stress tolerance is being screened among available genotypes of cereal crop species and their wild relatives (Nevo and Chen 2010; Shavrukov et al. 2010; Siahpoosh et al. 2011; Trethowan and Mujeeb-Kazi 2008; Xie and Nevo 2008), with the aim of building up a comprehensive gene pool to be used in breeding programmes.

Breeding for adaptation to environmental stresses has to face increasing uncertainty (Giampietro 2004; Prato 2008) in the occurrence of stress-generating climate events (Asseng et al. 2011; Ceccarelli et al. 2010). A crucial question is therefore: 'Which breeding and management strategies can be envisaged to ensure good crop performance in a stressful environment dominated by uncertainty?'

The availability of a large pool of cultivars may not be enough to face such uncertainty. Increased crop genetic heterogeneity, either by using cultivar mixtures (Finckh et al. 2000; Kaut et al. 2009) or heterogeneous evolutionary population like composite cross populations (Finckh 2008; Phillips and Wolfe 2005), may better cope with environmental uncertainty than the use of a single, homogeneous and locally adapted cultivar. In the case of evolutionary populations, progressive adaptation to local environments (David et al. 1997) has been documented regarding, e.g. improved winter survival (Hensleigh et al. 1992) or salt tolerance (Jana et al. 1980) in barley composite cross populations. Variation in wheat heading and flowering time (Rhoné et al. 2010) may be considered a stress avoidance strategy. When growing and reproducing subsets of the same wheat population in different climatic conditions for 10 years, Goldringer et al. (2006) observed a rapid divergent evolution for heading time according to local environments, a phenotypic expression of within-population genetic diversity.

Despite little research has been done on the relationship between intercropping and abiotic stress tolerance, evidence of improved nutrient (Morris and Garrity 1993a) or water (Morris and Garrity 1993b) use efficiency in cereal-legume intercrops suggests that species diversity can play an important role also in buffering environmental variation and uncertainty.

\subsection{Disease and pest reduction}

Crop disease resistance depends on complex interactions between pathogens, host crop and agro-ecosystem structure and management, which may span across different temporal and spatial scales. In the occasion of the worldwide outbreak of Ug99, a new strain of wheat stem rust (Puccinia graminis $\mathrm{f}$. sp. tritici), Ayliffe et al. (2008) highlighted the need for wheat stem rust resistance to be durable. In fact, it is known that cultivars tend to lose their resistance traits in a few years, especially if these are monogenic and race specific (Kilpatrick 1975). As a matter of fact, the large size of pathogens populations and their high number of generations make 
mutations so probable that host plant resistance can be very quickly overcome (Hollomon and Brent 2009). Although host-pathogen interactions can be unravelled through genomic tools, this problem is unlikely to be overcome in homogeneous (i.e. non-diversified) cropping systems (Ayliffe et al. 2008), unless genetic resistance is integrated with other measures (Mundt et al. 2002; Döring et al. 2012). Which breeding and management strategies would enable wheat crops to reduce disease occurrence and impact and to improve resistance durability?

As summarised by Fabre et al. (2012), resistance sources may be deployed either through a 'pure' strategy, i.e. relying on a uniform resistant cultivar, or through a 'mixture' strategy, i.e. mixing resistant and susceptible cultivars. In the medium to long term, widening the crop gene pool (Able et al. 2007) by exploring and conserving germplasm in ancient cultivars (Newton et al. 2010) and crop wild relatives (Hoisington et al. 1999; Olivera and Steffenson 2009; Valkoun 2001) would be essential to identify new resistance genes and mechanisms. As pointed out by Newton et al. (2010), resistance in modern widespread cereal cultivars mainly relies on hypersensitivitybased Mendelian traits. Instead, landraces and crop wild relatives have evolved polygenic resistance, which may significantly contribute to crop protection without the risks posed by single gene resistance. As a matter of fact, due to their partial, broad-spectrum nature, polygenic resistance may improve resistance durability (Kou and Wang 2010). Moreover, multiple resistance traits can be easily handled through QTL mapping (Czembor et al. 2003; Pereira et al. 2000) and markerassisted selection (Miedaner et al. 2009).

Agro-ecosystem diversification is amongst the most promising strategies to keep diseases and pests under control. As a matter of fact, disease control is the main aspect which diversification practices as cultivar mixtures have been studied for. The yield advantage of cultivar mixtures over pure stands of their components has been proven especially in the presence of diseases (Akanda and Mundt 1997; Kiær et al. 2009). This is due to a host diversity effect (Garret et al. 2006; Garret et al. 2009) whose efficacy is strictly linked to the epidemiological conditions of the disease and to life histories of the pathogens. As an example, Cox et al. (2004) hypothesised that host diversity would be more effective in reducing leaf rust (Puccinia triticina f. sp. tritici) than tan spot (Pyrenophora tritici-repentis), the first being a wind-dispersed, polycyclic, highly specialised pathogen while the second is a soil residueborne one. These authors, however, demonstrated that the severity of both diseases can be simultaneously reduced by mixing cultivars carrying different resistance levels.

In a longer perspective, genetically heterogeneous crop stands can also influence pathogen evolution (Finckh et al. 2000), since they reduce the reproduction of simple races, thus favouring complex races (Lannou and Mundt 1996; Lannou and Mundt 1997; Mundt 2002b). In addition, evolutionary processes driven by even higher crop genetic heterogeneity, as in composite cross populations, can conserve (De Smet et al. 1985, for barley and powdery mildew-Blumeria graminis f. sp. hordei) or even increase (Goldringer et al. 1998, for wheat and leaf rust) disease resistance.

Species diversity has also been proven to potentially hamper disease outbreaks (Trenbath 1993). As an example, the dispersal of Septoria tritici pycnidiospores in wheat was reduced by the presence of intercropped clover (Bannon and Cooke 1998). However, the effect of intercropping can be controversial. Microclimatic conditions may indeed favour wheat powdery mildew outbreaks in wheat-faba bean intercrops, especially when $\mathrm{N}$ fertilisers are added (Chen et al. 2007). It is worthwhile remembering that crop diversity across time, i.e. appropriate rotation planning, has a central role in disease control (Conway 1996; Kirkegaard et al. 2008; Ransom et al. 2007) and should be considered a prerequisite for any successful disease control strategy in any cropping/ farming system (Bennet et al. 2012; Reis et al. 2011).

Similarly to diseases, genetic host resistance is reported as a cheap and common means to counteract wheat insect pests such as aphids (El Bouhssini et al. 2011). Host-pest relationships are progressively better understood (Botha et al. 2005), including complex multi-trophic interactions among crops, weeds, pests and their natural enemies. The underlying hypothesis, worth of further work, is that crop stand heterogeneity at the genetic and/or species level may improve pest control either (a) directly, through a host dilution effect, especially against highly specialised, monophagous pests, or (b) indirectly, through a bottom-up effect resulting in enhanced overall activity of natural enemies.

Caballero-López et al. (2012) studied whether and how plant communities affect the richness and abundance of aphids and their interactions with natural enemies in winter cereals crops. They found clear bottom-up effects influenced by the cropping system, and that a higher presence of legumes in organic fields enhanced the richness of natural enemies. Diversifying crop stands is therefore a practical means to increase pest control through a cascade effect mediated by plant diversity.

Tooker and Frank (2012) reviewed the pest reduction effects that can be obtained by increasing crop genetic diversity through cultivar mixtures. Glen (2000) emphasised how weed presence may reduce the severity of aphids or slug attacks on wheat, similarly to what can be obtained by intercropping wheat and legumes.

Nevertheless, an extensive review by Ratnadass et al. (2012) showed that not necessarily higher diversity results in lower pests and/or disease attack on crop. Deeper understanding of the mechanisms driving the relationships between crop diversity and pests or diseases is needed to make cropping system diversification an effective and reliable tool. 


\subsection{Yield and yield stability}

Yield can be considered either as a trait or as an agro-ecosystem service. In many breeding studies, yield is viewed as a complex, low-heritable trait dominated by genotype-byenvironment-by-management interactions (Araus et al. 2008; Cooper et al. 2001). High yielding cultivars diffused after the Green Revolution have been embedded into a 'technological package' paradigm based on the compulsory use of high external inputs (Yapa 1977; 1993). A productive wheat cultivar would then correspond to the ideotype described by Donald (1968): a dwarf plant with few erect leaves and a single culm, carrying a large, erect and awned ear. However, this phenotype does not guarantee high yield unless a favourable, standardised environment is provided through external input supply (Desclaux et al. 2008). How can a wheat crop maintain or increase yields with low external inputs?

As pointed out by Marshall (1991), it is after Donald's proposal of the ideotype approach that morphological and physiological traits directly linked to yield have been targeted in breeding. In fact, many studies focusing on yield consider 'yield potential' as a trait independent from others (Reynolds et al. 2009). Wheat yield potential per se was mainly targeted through the increase in harvest index, achieved by exploiting dwarfing genes (Milach and Federizzi 2001). Recently, the main goals of breeding for increased yield are the enhancement of photosynthetic capacity and efficiency (Parry et al. 2010) and the increase of resource partitioning to grains (Foulkes et al. 2011). However, such goals would concretely ensure yield gains 'provided that other constraints do not become limiting' (Parry et al. 2010). Also, to maintain grain quality while increasing grain yield, 'crop $\mathrm{N}$ requirements will nevertheless increase' (Foulkes et al. 2011). Such approaches seem more in line with Donald's paradigm than with present challenges faced by low-input systems.

Donald (1968) postulated that 'a successful crop ideotype would be a weak competitor', in order to minimise crop intraspecific competition. This approach, widely used in conventional breeding programmes in the past 50 years, was embraced by Sedgley (1991) but questioned by Rasmusson (1991), who proposed that a large and competitive plant would be a better ideotype for barley. The latter author also stated that, rather than postulating a single ideotype for each crop, alternative breeding models within given ecological areas would be needed.

Besides breeding, the yield of a cereal crop stand can also be increased by appropriate cropping system design. Wide documentation exists of increased land equivalent ratio in mixtures of either species or genotypes, e.g. hanfets (Woldeamlak et al. 2008), various wheat-legume intercrops, e.g. durum wheat-winter pea (Bedoussac and Justes 2009) or wheat-faba bean (Agegnehu et al. 2008).

Yield advantages of cultivar or species mixtures have often been related to enhanced resistance to diseases or tolerance to abiotic stresses (Finckh et al. 2000; Trenbath 1993). Part of these yield gains can also be attributed to a direct 'mixing effect' (Stützel and Aufhammer 1990) due to improved resource use efficiency (Midmore 1993), as shown for water (Morris and Garrity 1993b), solar radiation (Tsubo et al. 2001 in maize-bean intercrops), nitrogen (Whitmore and Schröder 2007) and phosphorus (Betencourt et al. 2011; Li et al. 2008).

When looking at yield as an agroecosystem service, the goal is not only to obtain adequate yield, but also to increase yield stability. In breeding, yield stability is often regarded as the variation of a cultivar performance across locations, as compared to the average performance of a set of cultivars in the same locations (Cleveland 2001). Conventionally, yield stability has often been pursued through breeding for wide adaptation in order to reduce, or possibly ignore, the effects of genotype-by-environment interaction (Desclaux et al. 2008). In the context of low-input and organic farming, as highlighted by Wolfe et al. (2008), a key goal would be improving yield stability across time.

How can temporal variation in yield and the probability of yield falling below a specified level (Piepho 1998) be reduced? The temporal dimension of yield stability is an emerging property of an agroecosystem (Marten 1988) rather than being a mere genotype trait. Yield stability can be improved through breeding and cultivar choice as well as through cropping system design and management. Increased yield stability across space and time can often be achieved by cultivar mixtures without jeopardizing yield potential, as shown by Kiær et al. (2012), Mengistu et al. (2010) and Helland and Holland (2001), who proposed to use pure-line evaluation data for selecting superior mixtures and enabling farmers to select them.

These last examples claim for integrating a pure breeding approach (yield stability across space tested in multi-location trials) with an agroecological approach aiming to improve yield stability across time through locally tuned cultivar choice, diversification strategies and cropping system design. Temporal stability, indeed, can be assumed as strongly related with spatial stability and then partly predictable for cultivars by using data from multi-location cultivar evaluation trials. Piepho (1998) proposed accurate statistical methods to partition site and year effects, rather than consider them interchangeable, on the stability of cultivars and of a plurality of cropping system variables.

\section{Planned agrobiodiversity: functional categories and related strategies}

Despite the general consensus among scientists on the benefits that crop diversity can provide to agroecosystem services, our literature survey did not return consistent indications of how 
to improve wheat production through agrobiodiversity. This is likely due to existing conflicts between target services and to significant knowledge gaps on cause-effect relationships between crop heterogeneity and the expression of services. For example, in some cases, cereal-legume intercropping can improve nitrogen use efficiency, but increase disease occurrence (Chen et al. 2007). The question is then to ascertain whether or not, based on present knowledge, the functional role of agrobiodiversity can be clearly demonstrated and hence translated into practical recommendations for farmers.

\subsection{Three functional categories to address agrobiodiversity}

How can agrobiodiversity translate into better provision of services? This can happen through several and distinct mechanisms, whose applications to cropping system have so far not been clearly addressed in the scientific literature. The ecological debate on the role of biota in carrying functions in natural ecosystems can be helpful to understand the potential and limits of different agrobiodiversity use strategies in wheat production. Two main hypotheses, which are not mutually exclusive, have been proposed with reference to grassland ecosystems: (a) the 'mass ratio hypothesis', which proposes that the main determinants of ecosystem processes are the traits of dominant species (Grime 1998; Mokany et al. 2008), and (b) the 'diversity hypothesis', which proposes that the main determinant of ecosystem processes is the diversity of biota and of their functional roles in a community (Tilman et al. 1997; Fornara and Tilman 2009). In our hypothesis, the pathways with which the crop stand may influence the provisions of agroecosystem services belong to three categories (Table 1):

1. Functional identity, i.e. the presence of a set of homogeneous phenotypic traits that are related to the expression of given agroecosystem services

2. Functional composition, i.e. the complementary effect of different traits, expressed by co-occurring elements, on the provision of given agroecosystem services

3. Functional diversity, i.e. the direct effect of heterogeneity within the crop stand on the expression of given agroecosystem services

Functional identity is a key concept in the mass ratio hypothesis (Mokany et al. 2008) and can be applied to a wheat crop assuming the crop as the dominant species (sensu Grime 1998) in the agroecosystem. Therefore, if we assume as 'identity' the set of identifying traits that distinguish, e.g. one cultivar from any other and make it recognisable, functional identity can be seen as the part of this identity which is related to the provision of a service. From a breeding point of view, the proposed definition overlaps with the concept of ideotype, intended as the ideal combination of crop traits aimed at meeting a predefined objective in a given context
(Andrivon et al. 2013). An example of functional identity applied to a wheat crop cycle is the choice of a given cultivar-be it homogeneous or heterogeneous-for a specific objective. In this case, the key mechanism through which agrobiodiversity is made functional is indirect, being related to the availability of different identities to choose from, to better ensure the provision of target services. Functional identity would thus answer a question like: 'Do I need to cultivate a tall or dwarf wheat cultivar to improve weed suppression?'

Functional composition and functional diversity are related to the diversity hypothesis, as they both refer to heterogeneous crop stands. Although no univocal definition of these concepts has been agreed so far in the ecological literature, they both focus on the identification, within an ecosystem, of functional groups, i.e. clusters of elements (at the genetic, species or habitat level) carrying the same ecosystem function. In this context, functional composition mainly refers to the copresence of given functional groups, e.g. $\mathrm{N}_{2}$-fixing legumes and $\mathrm{C}_{4}$ grasses carrying complementary functions and thus enhancing the overall biomass productivity of a grassland ecosystem (Tilman et al. 1997). In wheat, an example of functional composition is mixing a high-yielding but disease-susceptible cultivar with a less-yielding but diseaseresistant one, to reduce disease outbreak and thereby yield loss (Finckh et al. 1999). Similarly, the co-presence of cereals and legumes, and not heterogeneity per se, is expected to improve resource use efficiency in intercropping systems. In both cases, the key mechanism is to combine elements expressing different yet complementary traits, to better ensure the provision of target services. Functional composition would thus answer a question like: 'Which legume species should I grow together with wheat to maximise the overall yield in an intercropping system?'

On the other hand, functional diversity may either refer to the number and diversity of functional groups present within the ecosystem, as addressed by Tilman et al. (1997), or to the diversity of elements within a functional group (Moonen and Bàrberi 2008). An example of functional diversity is using heterogeneous wheat populations (e.g. composite cross populations) instead of homogeneous pure lines to cope with climate unpredictability. In this case, the key mechanism is to better ensure the provision of target services by deliberately increasing the genetic heterogeneity of the crop stand. Functional diversity would thus answer a question like: 'How can I stabilise wheat yield in a context characterised by fluctuations between dry and wet years?'

Mokany et al. (2008) suggested that some ecosystem processes are mainly explained by functional diversity and/or composition, i.e. through the diversity hypothesis, while others are better explained by functional identity, i.e. through the mass ratio hypothesis. Therefore, it is important to remark that crop functional identity, composition and diversity are not alternatives. Rather, it is their combination that gives better 
Table 1 Functional categories proposed to address agrobiodiversity use in wheat production, their underlying ecological rationale and determinants, their related agroecosystem approaches, strategies and target services and their possibilities/needs of optimisation

\begin{tabular}{|c|c|c|c|}
\hline & Functional identity & Functional composition & Functional diversity \\
\hline Underlying hypothesis & $\begin{array}{l}\text { Mass ratio hypothesis } \\
\text { (Grime 1998; Mokany } \\
\text { et al. 2008) }\end{array}$ & $\begin{array}{l}\text { Diversity hypothesis } \\
\text { (Fornara and Tilman 2008) }\end{array}$ & $\begin{array}{l}\text { Diversity hypothesis } \\
\quad \text { (Tilman et al. 1997) }\end{array}$ \\
\hline $\begin{array}{l}\text { Determinant of ecosystem } \\
\text { processes }\end{array}$ & Traits of the dominant species & $\begin{array}{l}\text { Co-presence of complementary } \\
\text { functional groups }\end{array}$ & $\begin{array}{l}\text { Diversity among or within } \\
\text { functional groups }\end{array}$ \\
\hline Agroecosystem approaches & $\begin{array}{l}\text { Identifying useful crop traits: } \\
\text { definition of crop ideotypes } \\
\text { (Andrivon et al. 2013) }\end{array}$ & $\begin{array}{l}\text { Association of functionally different } \\
\text { crops/cultivars: cropping system } \\
\text { diversification (Malézieux et al. } \\
\text { 2009) }\end{array}$ & $\begin{array}{l}\text { Genetic heterogeneity of the } \\
\text { cultivar and evolutionary } \\
\text { breeding (Phillips and } \\
\text { Wolfe 2005) }\end{array}$ \\
\hline $\begin{array}{l}\text { Strategies to improve } \\
\text { wheat production }\end{array}$ & Breeding for ad hoc cultivars & $\begin{array}{l}\text { - Intercropping } \\
\text { - Living mulches } \\
\text { - Cultivar mixtures }\end{array}$ & $\begin{array}{l}\text { Dynamic management of } \\
\text { composite cross populations }\end{array}$ \\
\hline $\begin{array}{l}\text { Agroecosystem services } \\
\text { expected to improve }\end{array}$ & $\begin{array}{l}\text { - Weed reduction } \\
\text { - N use efficiency } \\
\text { - Tolerance of given abiotic } \\
\text { stresses } \\
\text { - Short-term disease resistance } \\
\text { - Yield and yield stability }\end{array}$ & $\begin{array}{l}\text { - Weed reduction } \\
\text { - N use efficiency } \\
\text { - Abiotic stress tolerance } \\
\text { - Disease and pest reduction } \\
\text { - Yield (land equivalent ratio) }\end{array}$ & $\begin{array}{l}\text { - Tolerance of abiotic stresses } \\
\text { - Disease and pest reduction } \\
\text { - Buffer unpredictable stresses } \\
\text { - Adaptation to the environment } \\
\text { - Progressive yield increase }\end{array}$ \\
\hline Required optimisations & $\begin{array}{l}\text { - Breeding in target environments } \\
\text { - Participatory breeding }\end{array}$ & $\begin{array}{l}\text { - Facilitate components choice } \\
\text { - Optimise the association } \\
\text { - Technical adaptation }\end{array}$ & $\begin{array}{l}\text { - Choice of the key traits to diversify } \\
\text { - Monitor intergenotypic } \\
\text { competition }\end{array}$ \\
\hline
\end{tabular}

opportunities to fully utilise agrobiodiversity to improve sustainability in a given agroecosystem. The interdependence among these categories should however be explored by addressing the following two critical issues. One is clarifying the relations between crop identity and crop heterogeneity to understand whether or not, and to which extent, these apparently diverging concepts can be integrated in heterogeneous crop stands. A second issue is partitioning crop stand heterogeneity to understand in which cases we should discriminate between functional composition- and functional diversitybased mechanisms (Table 1).

\subsection{Relations between crop identity and crop heterogeneity}

In organic and low-input cropping systems, the farmer's question: 'Which cultivar should I grow?' may have a broader answer than just the choice of a homogeneous cultivar. There is room to incorporate heterogeneity into the crop but, since the possibility of sowing a heterogeneous crop is not fully supported by the DUS system (Winkler et al. 2013), two major issues emerge. The first regards the identity of the crop stand. Here, heterogeneity aimed at disease reduction conflicts with uniformity, aimed to obtain a recognisable produce. The second issue regards the identity of seeds for crop propagation. Here, heterogeneity, expected, e.g. to enable local adaptation in composite cross populations, conflicts with the requisite of phenotypic stability.

\subsubsection{Identity and heterogeneity of the crop stand}

In a wheat crop stand, would heterogeneity and identity integrate or would they conflict? Much of the literature surveyed for weed reduction and $\mathrm{N}$ use efficiency refers an ecological framework similar to the mass ratio hypothesis, aiming to deploy a given set of traits in the crop stand (i.e. the dominant species). For example, a weed suppressive wheat crop is indeed supposed to be tall and fast-early growing. On the other hand, services like disease reduction have been thoroughly explored on the basis of a diversity hypothesis.

The major advantage of focusing on identity from a functional point of view, instead of just choosing from a range of homogeneous cultivars, is that the crop traits required to be mostly uniform can be addressed without necessarily maintaining a high homogeneity level in the entire phenotype. Fridley et al. (2007) suggested that effective grassland conservation and restoration rely not just on identifying 'the right genotypes', but also on ensuring genetic variation at a finer scale. Similarly, once clarified what is the desired 'functional identity' of a wheat crop stand, as regards, e.g. traits related to optimal weed suppressive ability or $\mathrm{N}$ use efficiency, there is 
room to integrate heterogeneity for other sets of traits, e.g. resistance to multiple diseases.

Functional identity can as well help clustering different cultivars into 'functional types' related to key traits or services. An example is the growing debate on employing old vs. modern wheat cultivars. Many works showed that key traits have changed throughout breeding development in the second half of the twentieth century, suggesting that old cultivars (those released from the earliest formal breeding programmes) may carry given functional identities that are different from modern cultivars. Besides the reduction in height obtained through exploitation of dwarfing genes, generally considered as a turning point in wheat improvement (Milach and Federizzi 2001), Isidro et al. (2011) and Motzo et al. (2007) reported on increased earliness and progressive loss of photoperiod sensitivity in Italian and Spanish modern durum wheat cultivars. Furthermore, Murphy et al. (2008) highlighted a progressive reduction in height and coleoptile length of spring wheat, possibly related to a decline in its weed suppression ability. Stagnari et al. (2013) clearly discriminated the good input responsiveness of modern cultivars against the good performance of old cultivars in limiting environments, encouraging the use of the latter in organic farming. In contrast, Guarda et al. (2004) suggested that modern cultivars are more suitable than old ones even in limiting environments, due to an intrinsically optimised $\mathrm{N}$ uptake and use efficiency. Lack of a general agreement on the use of old vs. modern cultivars in contemporary low-input and organic agriculture suggests that a functional identity approach should encompass the target agroecosystems and farmers' objectives, as well as social expectations, e.g. in terms of overall produce quality (Dinelli et al. 2013).

\subsubsection{Identity and heterogeneity of the seeds}

In an attempt of simplifying the problem of the identities 'to be sown', we assume that a farmer can either (a) sow a pure, uniform cultivar, (b) constitute a mixture of uniform cultivars or (c) sow and resow a heterogeneous bulk population. This raises the problem of the identity of seeds. In fact, while in the first and second cases we deal with known cultivars, in the third case, it needs to be clarified what we are dealing with. The crucial issue is that diverse populations, when propagated, are subjected to changes due to natural selection, plantplant interactions and environmental pressure. This is clearly contrasting with the requirements of cultivar distictness and phenotypic stability, i.e. the ability to exactly predict the identity of the material that we are growing.

Murphy et al. (1982) addressed the problem of the compositional stability of multiline cultivars, trying to understand whether these seeds would better be considered as cultivars or blends. Multilines are basically mixtures of near-isogenic, bulk-reproduced lines. The problem shown by these authors is a differential survival rate of near-isogenic lines across generations, and the risk that such changes in survival rates could be unpredictable and favour less useful genotypes. This problem is worsened when dealing with bulk populations where intraspecific competition may have an even stronger impact. Competition between tall and dwarf wheat genotypes was studied by reproducing both bulk physical mixtures (Khalifa and Qualset 1974) and bulk hybrid populations (Khalifa and Qualset 1975), showing a competitive advantage of tall genotypes and, in the case of hybrids, a net increase in height across generations, followed by stabilising selection for intermediate height.

In composite cross populations, there is evidence that macro-environmental conditions are the main determinants of natural selection-driven evolution, as demonstrated for a population grown over a decade in a multi-site experiment in France (David et al. 1997). An important role in shaping genotype frequencies in a composite cross population might also be played by specific stresses, as suggested by Ibrahim et al. (1996) for disease pressure. This evidence is useful to orientate evolution in the direction of target management regimes. For example, Thapa et al. (2010) successfully documented divergent shifts in growth habit of a bulk population reproduced in two contrasting cropping systems, one of which was conventional wheat growing while the other included grazing during vegetative stages. The population reproduced in the grazed system became more adapted to this doublepurpose wheat management. This suggests that management systems may be considered a selection tool and that, in reverse, intra-specific diversity enables populations to enhance their fitness in specific management systems.

The choice of parental germplasm can be very important in predicting the evolution of a composite cross population identity (Döring et al. 2011). Through parental choice, the sets of traits expected to be homogeneous are determined, resulting in the functional identity of the population. For example, in common wheat, it has been tried to obtain highly heterogeneous populations still expressing an identity similar to their parentals regarding high yield and/or quality (Wolfe et al. 2006).

Therefore, we can reasonably argue that heterogeneous populations like composite cross populations do have an identity, although continuously shaped by natural selection. Such dynamic identity cannot be conventionally certified, as evolutionary processes may significantly modify single genotype frequencies in different subsets of each population grown separately. In this perspective, a research effort would be needed to better describe evolutionary processes by (a) ascertaining the scale of local adaptation, (b) identifying stronger and weaker evolutionary pressures and (c) establishing criteria to determine whether or not separate subsets of the same original population can be considered different. This would also allow to foresee alternative cultivar identification approaches, useful to overcome the current illegal status of diverse seeds for trade and 
exchange in the European Union (Döring et al. 2011; Howard 2009). Current directions for an identification framework of evolutionary populations are to combine parental identity with cultivation history of the population in a 'certified traceability' system (Winkler et al. 2013).

\subsection{Functional composition and functional diversity of the crop stand}

Diversification can be implemented through a wide array of strategies, from improved crop rotation design and intercropping to (re)sowing heterogeneous populations. These strategies involve different ecological processes that need to be optimised. This can be facilitated by attributing each strategy to either functional composition or functional diversity, as shown by the scientific debate around grasslands. In fact, when compared to species richness and identity, both functional diversity and functional composition appear as the main determinants of plant productivity, plant $\mathrm{N}$ accumulation and light interception in grasslands (Tilman et al. 1997). Instead, some processes are better explained through functional composition effects. As an example, soil carbon and $\mathrm{N}$ accumulation rates, although increased in highly diverse mixtures of grassland species, are especially enhanced by the co-presence of $\mathrm{N}_{2}$-fixing legumes and $\mathrm{C}_{4}$ grasses (Fornara and Tilman 2008). On the other hand, the stability and buffer capacity of ecological processes possibly require functional diversity, as suggested by studies on genetically diverse crops and their enhanced resistance to biotic and abiotic stresses (Ceccarelli et al. 2010; Finckh 2008; Finckh et al. 2000).

\subsubsection{Functional composition in species and cultivar mixtures}

As most ecological studies addressed species diversity, it is easy to recognise the role of functional composition while dealing with intercropping or living mulch strategies. Once stated the main objective of these practices, e.g. weed suppression (Hartwig and Ammon 2002) or increased N use efficiency (Tosti and Guiducci 2010), the most important decision mainly addresses the functional identity of the two components, usually a cereal cultivar (Hiltbrunner and Liedgens 2008) and a legume species (Hiltbrunner et al. 2007b) or cultivar (Davis and Woolley 1993). Instead, it is less clear which mechanisms should we focus on when dealing with genetic diversity.

In cultivar mixtures, better yield performance is commonly found than in component cultivars (for a comprehensive discussion and quantification of mixture advantages, see Kiær et al. (2009)). However, little knowledge of the mechanisms driving this effect limits the application of this strategy (Juskiw et al. 2000; Kiær et al. 2012). In literature, mixture advantages in yield were often associated with the presence of specific limiting factors, such as diseases (Akanda and Mundt 1997; Newton and Guy 2009) or pests (Vera et al. 2013).
In fact, the potential of cultivar mixture in reducing diseases is the most studied aspect of this practice in many different crops (Wolfe 2000). Zhu et al. (2000) conducted a large-scale experiment in ten townships in the Yunnan Province, China, where mixed stands of rice blast (Magnaporthe grisea) resistant and susceptible rice cultivars outyielded the susceptible cultivar by nearly $90 \%$, leading local farmers to abandon fungicide spraying. Wolfe et al. (1987) reported that in the former German Democratic Republic, the use of barley cultivar mixtures during the 1980s allowed a large-scale reduction of powdery mildew outbreaks.

Cox et al. (2004) asserted that the presence of 'appropriate resistance genes targeted against specific pathogen populations' would be critical in ensuring mixture advantage in disease reduction as well as yield and yield stability improvement in the presence of multiple disease pressure. This suggested a prevailing role of functional composition over functional diversity and was confirmed in the meta-analysis by Kiær et al. (2009), who found a higher mixture advantage when component varieties differed for critical traits such as disease resistance levels or response to abiotic stresses and weed competition.

In cultivar mixtures, the choice of component genotypes then becomes crucial. Ecological research showed that performance, measured, e.g. as biomass production, of single genotypes varies when they are mixed (Fridley and Grime 2010). In fact, in both cultivar and species mixtures, the components should not be chosen based on their overall performance in pure stands, but rather on a set of critical traits enhancing their complementarity while minimising their competition when grown together. The composition of these traits will ultimately determine the desired, 'composite identity', i.e. functional composition, of the resulting crop stand.

Other factors are critical in predicting and enhancing cultivar mixture performance. Sowing proportion of different components has been addressed, e.g. by Lee et al. (2006) who found that performance of a binary mixture in terms of yield, grain protein content and baking quality was dependent on the seed ratios, and that the seed ratio effect changed across locations. Newton and Guy (2009) explored the effects of spatial heterogeneity of the mixture in barley, by modulating the homogenization of component seeds before sowing. Spatially homogeneous mixtures and 'patchy', imprecise mixtures, in which the actual proportions of component cultivar in the field varied randomly, were obtained and compared with or without fungicide application. They interestingly found a significant yield advantage in the patchy mixture only without fungicide application.

Similarly, functional composition effects in intercropping and living mulch systems are also related to other factors such as sowing densities (Blaser et al. 2006; Hiltbrunner et al. 2007c). In intercropping and living mulches, the life cycles of the two components usually differ much more than in cultivar mixtures. Hence, modulating the period of co-presence is critical to meet 
farmer objectives, minimise competition between components and ensure a good establishment of both of them.

Many intercropping designs are based on concurrent sowing of the two species, as in the work of Bedoussac and Justes (2009) and Poggio (2005), who addressed pea as a companion crop for the cereal. In some intercropping and/or living mulch designs, the cereal crop is sown in a previously established stand of a perennial legume. In many of the cited experiments ran in central and northern Europe, the living mulch was sown as a cover crop during summer (Hiltbrunner et al. 2007a, b, c; Hiltbrunner and Liedgens 2008; Thorsted et al. 2006a, b). In Bergkvist (2003), white clover was undersown in barley followed by two consecutive seasons of wheat-living mulch. In contrast, in other living mulch designs, the companion crop was sown into an already established main crop. In Carof et al. (2007a, b), different leguminous and grass-living mulches were sown in early spring into an autumn-sown wheat in a no-till system. Instead, in southern Europe, concurrent sowing of cereal and legume companion crops is common and has been studied, e.g. by Vasilakoglou et al. (2008) and Tosti and Guiducci (2010). In this latter work, it is proposed to plough in the legume before the cereal reaches the reproductive phase.

This variation in system design is related to the species chosen, its climatic limits and life cycle, to the pedoclimatic context and, obviously, to farmers' priorities and objectives. As an example, in the north central USA, Blaser et al. (2006) and Singer et al. (2006) worked on optimising the practice of winter undersowing of red clover in an autumn-sown cereal stand to maximise red clover forage production. In contrast, the system proposed by Tosti and Guiducci (2010) was mainly aimed at optimising $\mathrm{N}$ availability for the cereal. Furthermore, many systems respond to different objectives, as whole-crop harvest for forage and silage production, whose yield and quality can be improved by cereal-legume intercropping as compared to monocrops (Lithourgidis et al. 2007, 2010, 2011b).

Besides accurate component choice, functional composition effects can also be addressed through dedicate breeding programmes. In this respect, Hill (1996) proposed co-breeding programmes, i.e. mixing the components since the early stages of breeding to select for enhanced mixture performance, similarly to what was envisaged by Davis and Woolley (1993) for intercropping.

\subsubsection{Functional genetic diversity in a dynamic perspective}

The use of heterogeneous populations like composite cross populations in evolutionary breeding relies on the hypothesis that high genetic heterogeneity enables adaptation in variable and unpredictable contexts (Ceccarelli et al. 2010; Finckh 2008; Phillips and Wolfe 2005). Depending on the choice of parental germplasm for the initial cross, the genetic diversity of a composite cross population may be at the same time low for some traits, which will ultimately determine the population's identity, and very high for other traits, which will be those most exposed to natural selection. Genetic diversity in composite cross populations may even be enhanced by the insertion of male sterility genes into the mainly self-pollinating wheat population to maintain a certain rate of cross-pollination across generations. For example, in the European composite cross populations mentioned in Section 4.2.2, a further set of naturally occurring male sterile hybrids was included in the high-quality, high-yield and yield quality bulks of F2 progenies (Wolfe et al. 2006).

In composite cross populations, phenotypic variation of a high number of traits, and not the precise combination between a possibly enormous number of single genotypes, is the main determinant of the expected advantages, in a functional diversity perspective. Consequently, as much diversity as possible (e.g. populations in early generations) should be deployed in target cropping systems to enhance adaptation to those environments (Ceccarelli et al. 2010) or to management (Thapa et al. 2010). This documented potential for adaptability (Wolfe et al. 2013) suggests that functional diversity is an asset for going even beyond agroecosystem sustainability, towards a perspective of adaptive agroecosystem management (Jackson et al. 2010).

Nevertheless, a comprehensive picture of the implications of within-population diversity is still lacking. Present knowledge has shown how evolutionary dynamics in composite cross populations related to external selection pressures may lead to progressive adaptation and performance improvement, but two major questions remain open.

The first is the effect of plant-plant interactions within the population on evolutionary dynamics and its impact on population performance, already discussed in Phillips and Wolfe (2005). On this subject, Döring et al. (2011) raised three points: (a) the evolutionary advantage of genotypes producing more and smaller kernels over those producing less and larger kernels, (b) a possible population drift towards the prevalence of highly competitive, but agronomically poor genotypes, as already pointed out by Murphy et al. (1982), and (c) a possible trade-off between yield increase and end-use quality, e.g. grain protein content. Knapp et al. (2013) suggested that important inter-annual variation may mask environment-driven selection and that selection may occur toward adaptation to grow in mixture, with potential loss of useful mutant alleles previously selected in conventional breeding.

The second question addresses the effect of crop genetic diversity on weed reduction and nitrogen use efficiency. Some grassland experiments offer interesting insights on how genetic heterogeneity of coexisting populations may shape plant communities. Trait variation (Bilton et al. 2010), morphology variation and interspecific neighbouring relationships (Fridley et al. 2007; Whitlock et al. 2010) can favour interspecific competitive equivalence and species equitability (Fridley and Grime 2010). In an arable system, would these effects result in a competitive advantage of the crop over the weeds? Under which conditions? 


\section{Discussion}

We proposed the use of three functional categories, functional identity, functional composition and functional diversity, to better frame the mechanisms ensuring positive agrobiodiversity effects. These categories are not mutually exclusive. On the contrary, their integration opens the path for new innovation strategies. A wheat cultivar with a functional identity aimed at providing a given service, e.g. weed reduction, could comprehend an amount of functional diversity, e.g. to buffer climatic unpredictability, and be associated with a companion crop, e.g. to improve $\mathrm{N}$ use efficiency through functional composition effects. The utility of this framework has to be tested, however, in relation with concrete innovation strategies embedded in concrete cropping, farming and agricultural systems (sensu Borin and Ceccon 2002). The implementation of strategies related to each of the functional categories and the contribution of the proposed framework to future developments in agroecology are hereafter discussed.

How can a functional identity be defined and obtained? The key traits of a functional identity can hardly be defined irrespective of the agroecosystem in which they are supposed to work. There is increasing experimental evidence that higher yield in organic wheat can be better obtained through direct selection in organic farming systems rather than through indirect selection in conventional systems (Murphy et al. 2007). Hence, specific breeding programmes for organic or low-input cropping systems (Arterburn et al. 2012) should be encouraged, in order to reduce reliance of these systems on conventional breeding that often provides suboptimal cultivars. However, this would only solve part of the problem, as organic and low-input cropping systems have an intrinsically higher environmental variation than conventional systems. It is worth remembering that Dambroth and El Bassam (1983) defined 'low-input varieties' as 'adapted for specific ecological and growth conditions'. Literature reviewed for $\mathrm{N}$ use efficiency suggests that functional identities related to this service are better defined as embedded into specific pedoclimatic conditions, rather than according to an absolute potential to provide the service (Baresel et al. 2008; Sylvester-Bradley and Kindred 2009). This should then encourage organization of decentralised breeding programmes, which has already proven more efficient than centralised ones in marginal areas (Ceccarelli 1994). The inclusion of farmers in decentralised participatory plant breeding programmes (Ceccarelli et al. 2000,2003 ) would also allow meeting the objectives and needs of local farming systems, in terms of environmental adaptation, end-use expectations and technical, ecological, social and economic constraints (Desclaux et al. 2012).

Are functional composition effects easy to obtain? The use of cultivar mixtures, intercropping and living mulches is more limited than we would expect according to the results of scientific works. System design, in terms of adequate choice of components (cultivars and/or species to mix), their proportions and the modality of their deployment in the field, may represent a bottleneck that hinders the spread of these strategies. As pointed out by Kiær et al. (2012), it is unrealistic to provide farmers the amount of information necessary to plan cultivar mixtures, given the limited time of commercial cultivars availability on the market, as many cultivar combinations and relative seed rates would need to be tested. Some methods have been proposed to speed up the identification of optimal cultivar combinations. A first approach suggests that testing binary mixtures in wheat would enable discarding suboptimal pairs and thus facilitate the constitution of complex mixtures (Lopez and Mundt 2000; Mille et al. 2006). A second approach encourages the direct use of pure-line evaluation data to constitute useful mixtures, as proposed by Helland and Holland (2001) and Kiær et al. (2012). Both approaches can be facilitated through a research effort aimed at (a) identifying the critical traits influencing the combining ability and intraspecific competition, e.g. tillering or height, and (b) broadening the range of traits analysed in cultivar evaluation trials. If these information were available, the use of cultivar mixtures would meet specific objectives rising from local constraints or needs, such as reduction of given diseases, yield stabilisation or ensuring given quality parameters.

Functional composition effects sought by species associations imply deeper modification of the cropping system compared to a wheat sole crop. System design should indeed respond to farmers' objectives, pedoclimatic constraints and technical feasibility. Fukai and Midmore (1993) proposed a seven-step, cyclic method to conduct adaptive research on intercropping in farmers' fields: (a) identification of the expected agronomic and economic advantage, (b) determination of candidate crops responsiveness to major limiting factors, (c) choice of associated crops, (d) determination of interspecific competitiveness, (e) adjustment of interspecific competitiveness, (f) cultivar choice and (g) identification of new system designs or new associations. These authors emphasised how technical adaptation to manage mixed-species systems can be a major bottleneck for farmers' adoption: species associations requiring little adaptation effort were more easily adopted by farmers. Methods to facilitate the optimisation of both cultivar and species associations emphasise that priority efforts should be directed to (a) increase information on crop traits related to ecosystem services and intra- and interspecific relations and (b) test decision support systems facilitating the planning and optimisation of cultivar and species associations as embedded in local agroecosystems.

How to optimise crop functional diversity effects? Legal restrictions to the commercialisation and use of heterogeneous seeds are so limiting nowadays (Winkler et al. 2013) that implications, advantages and disadvantages of this approach to functional diversity are hard to discuss because of the lack of concrete experiences. However, we can foresee that functional 
genetic diversity can be useful for given traits and disadvantageous for other traits which, in turn, are better addressed through a functional identity approach. Discrimination between these two sets of traits, again, has to be sought in local agroecosystems and may be facilitated by the approach of composite cross populations. The choice of parentals may indeed direct the functional identity of the population, e.g. towards a high grain quality (Wolfe et al. 2006), while ensuring a high diversity for other traits, e.g. disease resistance (Goldringer et al. 1998) or adaptation to given management regimes (Thapa et al. 2010), that would be submitted to (agro)environmental selection in a plurality of contexts (Enjalbert et al. 2011).

Practical limits to the use of functional genetic diversity arise when, for some traits, there is a trade-off between the ecological value of diversity and its technical management. As an example, high variation in flowering time can buffer unpredictable environmental stresses (Kairudin 1991) and fasten evolution of locally adapted populations, but it can result as well in heterogeneous ripening, which can be a problem for mechanical harvest. Genetically diverse cultivars may also pose two orders of sanitary problems: (a) local seed saving and resowing, which is the key process of the evolutionary breeding approach, may indeed increase vulnerability to seed-borne diseases (Döring et al. 2011) and (b) fully disease-susceptible genotypes may occur in the offspring of crosses, which would need careful screening before population bulking and release in the field. Research is nowadays focussing on these sanitary issues (Borgen 2013). The risk that intra-specific competition could select for less useful genotypes is a further disadvantage of increased functional diversity (Knapp et al. 2013). On the other hand, the general advantage of diverse populations is that their evolution can easily be directed, corrected or fastened by direct selection (Dawson and Goldringer 2012). In parallel, we think that defining boundaries, in terms of both 'which traits to diversify' and 'how much diversity to confer to these traits' could help designing, constituting and managing useful diverse wheat populations.

Moving beyond the field scale, general limits and threats to the strategies taken into account in this review may arise. An example is the limitedness of disease reduction strategies when addressed only at a field scale. For example, Carson (2009) showed that oat multiline cultivars may also select for complex virulence and 'super-races' of crown rust (Puccinia coronata f. sp. avenae). This suggests that no cultivar, be it homogeneous or heterogeneous, can provide a fully durable resistance. Hence, the approach of resistance deployment on a landscape scale is gaining interest (Fabre et al. 2012; Garret et al. 2006; Papaix et al. 2011).

Can agrobiodiversity-based innovations exhaustively respond to worldwide challenges for future agroecosystems? At a global scale, projections for significant rise of food demand in the near future (Jaggard et al. 2010) and for negative impacts of climate change over agricultural productivity (Olesen et al. 2011) are nowadays milestones for future developments in agriculture. The dramatic increase in yields obtained in the second half of the twentieth century has been strongly dependent on external inputs (Reidsma et al. 2010), a paradigm which is increasingly questioned for its environmental impact and, as such, not really suitable as mainstream for future developments (Cassman 1999). Furthermore, current cereal yields are widely reported to be stagnating in Europe due to low resource use efficiency in cropping systems (Mueller et al. 2012), increased vulnerability to environmental unpredictable variation (Olesen et al. 2011) and also agronomic causes, like cropping system simplification and reduced inclusion of legumes in rotations (Brisson et al. 2010).

We think that framing agrobiodiversity use according to functional identity, functional composition and functional diversity can play a role in the paradigm of ecological intensification, as addressed by Doré et al. (2011), i.e. agroecosystem management based on ecological processes and biological regulation. In this context, we think that the contribution of agroecology, as a science, a movement and a practice (Wezel et al. 2009) would be very important to direct future developments in agriculture.

\section{Conclusion}

Under the umbrella of agrobiodiversity for sustainable wheat production, we found a wide range of hypotheses, objectives and solutions. Breeding of ad hoc cultivars, integrating legumes in the crop stand, using cultivar mixtures and implementing new approaches like evolutionary breeding are all pathways to enhance the provision of key agroecosystem services. Nevertheless, although sharing a common goal, these strategies rely on different ecological bases. Present knowledge does not address this clearly, thereby limiting the efficacy of agrobiodiversity-based solutions.

To be successful, the use of agrobiodiversity should be embedded in the agroecosystem design. Too often, the quest for alternative, sustainable cropping systems has led to mimic conventional cropping systems by prioritising input substitution, as, e.g. seen for organic farming 'conventionalisation' (Darnhofer et al. 2010). In contrast, agrobiodiversity should better be considered as the basis to redesign sustainable agroecosystems by mimicking natural ecosystems (Malézieux 2012). Concrete achievements in making wheat production more sustainable will depend on further understanding the mechanisms linking crop traits to agroecosystem services.

Functional identity, functional composition and functional diversity can constitute a useful framework to encompass the plurality of agrobiodiversity-based solutions by better targeting the links between crop traits and agroecosystem services. Moreover, these interdependent 
functional categories can be directly linked with strategic, tactic and operational issues, allow deeper integration between breeding and management and thus fully highlight the potential of agrobiodiversity to concretely improve sustainability.

Acknowledgments Part of this work has been carried out with the support of the EU-funded Projects SOLIBAM (Grant agreement no. FP7-KBBE 245058) and OSCAR (Grant agreement no. FP7-KBBE 289277) and of the ERA-NET Core Organic II Project TILMAN-ORG.

\section{References}

Able JA, Langridfe P, Milligan AS (2007) Capturing diversity in the cereals: many options but little promiscuity. Trends Plant Sci 12(2): 71-79. doi:10.1016/j.tplants.2006.12.002

Agegnehu G, Ghizaw A, Sinebo W (2008) Yield potential and land-use efficiency of wheat and faba bean mixed intercropping. Agron Sust Dev 28:257-263. doi:10.1051/agro:2008012

Agrama HA (2006) Application of molecular markers in breeding for nitrogen use efficiency. J Crop Improv 15:175-211. doi:10.1300/ J411v15n02 06

Akanda SI, Mundt CC (1997) Effect of two-component cultivar mixtures and yellow rust on yield and yield components of wheat. Plant Pathol 46:566-580. doi:10.1046/j.1365-3059.1997.d01-37.x

Almekinders CJM, Elings A (2001) Collaboration of farmers and breeders: participatory crop improvement in perspective. Euphytica 122:425-438. doi:10.1023/A:1017968717875

Andrivon D, Giorgetti C, Baranger A, Calonnec A, Cartolaro P, Faivre R, Guyader S, Lauri PE, Lescourret F, Parisi L, Ney B, Tivoli B, Sache I (2013) Defining and designing plant architectural ideotypes to control epidemics? Eur J Plant Pathol 135:611-617. doi:10.1007/ s10658-012-0126-y

Araus JL, Slafer GA, Royo C, Serret MD (2008) Breeding for yield potential and stress adaptation in cereals. Crit Rev Plant Sci 27: 377-412. doi:10.1080/07352680802467736

Arterburn M, Murphy K, Jones SS (2012) Wheat: breeding for organic farming systems. In: Lammerts van Bueren ET, Myers JR (eds.) Organic crop breeding. Wiley-Blackwell, Hoboken, pp. 163-174. ISBN 978-0-470-95858-2

Asseng S, Foster I, Turner NC (2011) The impact of temperature variability on wheat yields. Glob Change Biol 17:997-1012. doi:10. 1016/S1161-0301(01)00149-6

Atlin GN, Baker RJ, McRae KB, Lu X (2000) Selection response in subdivided target regions. Crop Sci 40:7-13. doi:10.2135/ cropsci2000.4017

Austin RB (1999) Yield of wheat in the United Kingdom: recent advances and prospects. Crop Sci 39:1604-1610. doi:10.2135/cropsci1999. $3961604 x$

Ayliffe M, Singh R, Lagudah E (2008) Durable resistance to wheat stem rust needed. Curr Opin Plant Biol 11:187-192. doi:10.1016/j.pbi. 2008.02.001

Baddeley J, Rees B, Bingham I, Watson C (2006) Nitrogen transfer from red and white clover to spring barley. In: Østergård H, Fontaine L (eds.) Proceedings of the COST SUSVAR Workshop on Cereal Crop Diversity: Implications for Production and Products. La Besse (France), 13-14 June 2006

Banik P (1996) Evaluation of wheat (Triticum aestivum) and legume intercropping under 1:1 and 2:1 row-replacement series system. J Agron Crop Sci 176:285-294. doi:10.1111/j.1439-037X.1996.tb00473.x

Bannon FJ, Cooke BM (1998) Studies on dispersal of Septoria tritici pycnidiospores in wheat-clover intercrops. Plant Pathol 47:49-56. doi:10.1046/j.1365-3059.1998.00200.x
Bàrberi P (2002) Weed management in organic agriculture: are we addressing the right issues? Weed Res 42:177-193. doi:10.1046/j. 1365-3180.2002.00277.x

Bàrberi P, Burgio G, Dinelli G, Moonen AC, Otto S, Vazzana C, Zanin G (2010) Functional biodiversity in the agricultural landscape: relationships between weeds and arthropod fauna. Weed Res 50:388 401. doi:10.1111/j.1365-3180.2010.00798.x

Baresel JP, Zimmermann G, Reents HJ (2008) Effects of genotype and environment on $\mathrm{N}$ uptake and $\mathrm{N}$ partitioning in organically grown winter wheat (Triticum aestivum L.) in Germany. Euphytica 163: 347-354. doi:10.1007/s10681-008-9718-1

Barraclough PB, Howarth JR, Jones J, Lopez-Bellido R, Parmar S, Shepherd CE, Hawkesford MJ (2010) Nitrogen efficiency of wheat: genotypic and environmental variation and prospects for improvement. Eur J Agron 33:1-11. doi:10.1016/j.eja.2010.01.005

Bedoussac L, Justes E (2009) The efficiency of a durum wheat-winter pea intercrop to improve yield and wheat grain protein concentration depends on N availability during early growth. Plant Soil 330:19 35. doi:10.1007/s11104-009-0082-2

Belz RG (2007) Allelopathy in crop/weed interactions - an update. Pest Manag Sci 63:308-326. doi:10.1002/ps. 1320

Bennet AJ, Bending GD, Chandler D, Hilton S, Mills P (2012) Meeting the demand for crop production: the challenge of yield declines in crops grown in short rotations. Biological Rev 87:52-71. doi:10. 1111/j.1469-185X.2011.00184.x

Bergkvist G (2003) Effect of white clover and nitrogen availability on the grain yield of winter wheat in a three-season intercropping system. Acta Agric Scand Sect B Soil Plant Sci 53:97-109

Bertholdsson NØ (2011) Use of multivariate analysis to separate allelopathic and competitive factors influencing weed suppression ability in winter wheat. Weed Res 51:273-283. doi:10.1111/j.1365-3180. 2011.00844.x

Betencourt E, Duputel M, Colomb B, Desclaux D, Hinsinger P (2011) Intercropping promotes the ability of durum wheat to increase rhizosphere phosphorous availability in a low P soil. Soil Biol Biochem 46:181-190. doi:10.1016/j.soilbio.2011.11.015

Bilton MC, Whitlock R, Grime JP, Marion G, Pakeman RK (2010) Intraspecific trait variation in grassland plant species reveals finescale strategy trade-offs and size differentiation that underpins performance in ecological communities. Botany 88:939-952. doi:10. 1139/B10-065

Blaser BC, Gibson LR, Singer JW, Jannink J-L (2006) Optimizing seeding rates for winter cereal grains and frost-seeded red clover intercrops. Agron J 98:1041-1049. doi:10.2134/agronj2005.0340

Borgen A (2013) Improved quality and disease management in diverse populations. In: Döring T, Howlett S, Winkler L, Wolfe MS (eds.) Proceedings of the International Symposium on Evolutionary Breeding in Cereals, Aston University, Birmingham (UK), 21 January 2013. The Organic Research Centre, Hamstead Marshall, UK, p. 7 (full proceedings available at http://orgprints.org/ 22440/)

Borin M, Ceccon P (2002) I sistemi colturali nella ricerca agronomica: un problema di scala. In: Bonari E, Ceccon P (eds) Verso un approccio integrato allo studio dei sistemi colturali. Franco Angeli, Milano, pp 11-43. ISBN: 9788846440709

Botha AM, Li Y, Lapitan NLV (2005) Cereal host interactions with Russian wheat aphid: a review. J Plant Interact 1:211-222. doi:10. 1080/17429140601073035

Brisson N, Gate P, Gouache D, Charmet G, Oury FX, Huard F (2010) Why are wheat yields stagnating in Europe? A comprehensive data analysis for France. Field Crops Res 119:201-212. doi:10.1016/j. fcr.2010.07.012

Brown AHD, Hodgkin T (2007) Measuring, managing, and maintaining crop genetic diversity on farm. In: Jarvis D, Padoch C, Cooper HD (eds.) Managing biodiversity in agricultural systems. Columbia University Press, New York, pp. 13-33. ISBN: 978-0-231-13648-8 
Caballero-López B, Blanco-Moreno J, Pérez-Hidalgo N, MichelenaSaval JM, Pujade-Villar J, Guerrieri E, Sánchez-Espigares J, Sans FX (2012) Weeds, aphids, and specialist parasitoids and predators benefit differently from organic and conventional cropping of winter cereals. J Pest Sci 85:81-88. doi:10.1007/s10340-011-0409-7

Callaway MB (1992) A compendium of crop varietal tolerance to weeds. Am J Altern Agric 7:169-180. doi:10.1017/S088918930000477X

Carof et al (2007a) Undersowing wheat with different living mulches in a no-till system. I. Yield analysis. Agron Sust Dev 27:347-356. doi: 10.1051/agro:2007016

Carof et al (2007b) Undersowing wheat with different living mulches in a no-till system. II. Competition for light and nitrogen. Agron Sust Dev 27:357-365. doi:10.1051/agro:2007017

Carson ML (2009) Crown rust development and selection for virulence in Puccinia coronata f. sp. Avenae in an oat multiline cultivar. Plant Dis 93:347-353. doi:10.1094/PDIS-93-4-0347

Cassman KG (1999) Ecological intensification of cereal production systems: yield potential, soil quality, and precision agriculture. Proc Natl Acad Sci U S A 96:5952-5959. doi:10.1073/pnas.96.11.5952

Ceccarelli S (1989) Wide adaptation: how wide? Euphytica 40:197-205. doi:10.1007/BF00024512

Ceccarelli S (1994) Specific adaptation and breeding for marginal conditions. Euphytica 77:205-219. doi:10.1007/BF02262633

Ceccarelli S (1996) Adaptation to low/high input cultivation. Euphytica 92:203-214. doi:10.1007/BF00022846

Ceccarelli S, Grando S, Tutwiler R, Baha J, Martini AM, Salahieh H, Goodchild A, Michael M (2000) A methodological study on participatory barley breeding. I. Selection phase. Euphytica 111:91-104. doi:10.1023/A:1003717303869

Ceccarelli S, Grando S, Singh M, Michael M, Shikho A, Al Issa M, Al Saleh A, Kaleonjy G, Al Ghanem SM, Al Hasan AL, Dalla H, Basha S, Basha T (2003) A methodological study on participatory barley breeding. II. Response to selection. Euphytica 133:185-200. doi:10. 1023/A:1025535609828

Ceccarelli S, Grando S, Maatougui M, Michael M, Slash M, Haghparast R, Rahmanian M, Taheri A, Al-Yassin A, Benbelkacem A, Labdi M, Mimoun H, Nachit M (2010) Plant breeding and climate changes. J Agric Sci 148:627-637. doi:10.1017/S0021859610000651

Chen Y, Zhang F, Tang L, Zheng Y, Li Y, Christie P, Li L (2007) Wheat powdery mildew and foliar $\mathrm{N}$ concentrations as influenced by $\mathrm{N}$ fertilization and belowground interactions with intercropped faba bean. Plant Soil 291:1-13. doi:10.1007/s11104-006-9161-9

Cleveland DA (2001) Is plant breeding science objective truth or social construction? The case of yield stability. Agric Hum Values 18:251270. doi:10.1023/A:1011923222493

Coleman RK, Gill GS, Rebetzke GJ (2001) Identification of quantitative trait loci for traits conferring weed competitiveness in wheat (Triticum aestivum L.). Australian J of Agric Res 52:1235-1246. doi:10.1071/AR01055

Comadran J, Russel JR, Van Eeuwijk FA, Ceccarelli S, Grando S, Baum M, Stanca AM, Pecchioni N, Mastrangelo AM, Akar T, Al-Yassin A, Benbelkacem A, Choumane W, Ouabbou H, Dahan R, Bort J, Araus JL, Pswarayi A, Romagosa I, Hackett CA, Thomas WTB (2008) Mapping adaptation of barley to droughted environments. Euphytica 161:35-45. doi:10.1007/s10681-007-9508-1

Conway KE (1996) An overview of the influence of sustainable agricultural systems on plant diseases. Crop Prot 15:223-228. doi:10.1016/ 0261-2194(95)00119-0

Cooper M, Woodruf DR, Phillips IG, Basford KE, Gilmour AR (2001) Genotype-by-management interactions for grain yield and grain protein concentration of wheat. Field Crops Res 69:47-67. doi:10. 1016/S0378-4290(00)00131-3

Cosser ND, Gooding MJ, Thompson AJ, Froud-William RJ (1997) Competitive ability and tolerance of organically grown wheat cultivars to natural weed infestations. Ann Appl Biol 130:523-535. doi: 10.1111/j.1744-7348.1997.tb07679.x
Cousens RD, Mokhtari S (1998) Seasonal and site variability in the tolerance of wheat cultivars to interference from Lolium rigidum. Weed Res 38:301-307. doi:10.1046/j.1365-3180.1998.00097.x

Cowger C, Weisz R (2008) Winter wheat blends (mixtures) produce a yield advantage in North Carolina. Agron J 100:169-177. doi:10. 2134/agronj2007.0128

Cox TS, Wood D (1999) The nature and role of crop biodiversity. In: Wood D, Lenné JM (eds) Agrobiodiversity: characterization, utilization and management. $\mathrm{CAB}$ International, Wallingford

Cox CM, Garret KA, Bowden RL, Fritz AK, Dendy SP, Heer WF (2004) Cultivar mixtures for the simultaneous management of multiple diseases: tan spot and leaf rust of wheat. Phytopathology 94:961969. doi:10.1094/PHYTO.2004.94.9.961

Czembor PC, Arseniuk E, Czaplicki A, Song Q, Cregan PB, Ueng PP (2003) QTL mapping of partial resistance in winter wheat to Stagonospora nodorum blotch. Genome 46:546-554. doi:10.1139/ g03-036

Dambroth M, El Bassam N (1983) Low input varieties: definition, ecological requirements and selection. Plant Soil 72:365-377. doi: 10.1007/BF02181974

Darnhofer I, Lindenthal T, Bartel-Kratochvil R, Zollitsch W (2010) Conventionalisation of organic farming: from structural criteria towards an assessment based on organic principles. A review. Agron Sust Dev 30:67-81. doi:10.1051/agro/2009011

David JL, Zivy M, Cardin ML, Brabant P (1997) Protein evolution in dynamically managed populations of wheat: adaptive responses to macro-environmental conditions. Theor Appl Gen 96:932-941. doi: $10.1007 / \mathrm{s} 001220050644$

Davies DB, Sylvester-Bradley R (1995) The contribution of fertilizer nitrogen to leachable nitrogen in the UK: a review. J Sci Food Agric 68:399-406. doi:10.1002/jsfa.2740680402

Davis JHC, Woolley JN (1993) Genotypic requirement for intercropping. Field Crop Res 34:407-430. doi:10.1016/0378-4290(93)90124-6

Dawson JC, Goldringer I (2012) Breeding for genetically diverse populations: variety mixtures and evolutionary populations. In: Lammerts van Bueren ET, Myers JR (eds.) Organic crop breeding. Wiley-Blackwell, Hoboken, pp. 77-98, ISBN 978-0-47095858-2

De Smet GMW, Scharen AL, Hockett EA (1985) Conservation of powdery mildew resistance genes in three composite cross populations of barley. Euphytica 34:265-272. doi:10.1007/BF00022918

Den Hollander NG (2012) Growth characteristics of several clover species and their suitability for weed suppression in a mixed cropping design. Thesis, Wageningen University, Wageningen NL. ISBN 978-94-6173-268-2

Desclaux D, Nolot J, Chiffoleau Y, Gozé E, Leclerc C (2008) Changes in the concept of genotype $\mathrm{x}$ environment interactions to fit agriculture diversification and decentralized participatory plant breeding: pluridisciplinary point of view. Euphytica 163:533. doi:10.1007/ s10681-008-9717-2

Desclaux D, Ceccarelli S, Navazio J, Coley M, Trouche G, Aguirre S, Weltzien, Lançon J (2012) Centralized or decentralized breeding: the potential of participatory approaches for low-input and organic agriculture. In: Lammerts van Bueren ET, Myers JR (eds.) Organic crop breeding. Wiley-Blackwell, Hoboken, pp. 99-123. ISBN 978$0-470-95858-2$

Dinelli G, Marotti I, Di Silvestro R, Bosi S, Bregola V, Accorsi M, Di Loreto A, Benedettelli S, Ghiselli L, Catizone P (2013) Agronomic, nutritional and nutraceutical aspects of durum wheat (Triticum durum Desf.) cultivars under low input agricultural management. Italian J Agron 8:85-93. doi:10.4081/ija.2013.e12

Doltra J, Olesen JE (2013) The role of catch crops in the ecological intensification of spring cereals in organic farming under Nordic climate. Europ J Agron 44:98-108. doi:10.1016/j.eja.2012.03.006

Donald CM (1968) The breeding of crop ideotypes. Euphytica 17:385403. doi:10.1007/BF00056241 
Doré T, Makowski D, Malézieux E, Mounier-Jolain N, Tchamitchian M, Tittonell P (2011) Facing up to the paradigm of ecological intensification in agronomy: revisiting methods, concepts and knowledge. Eur J Agron 34:197-210. doi:10.1016/j.eja.2011.02.006

Döring TF, Knapp S, Kovacs G, Murphy K, Wolfe MS (2011) Evolutionary plant breeding in cereals: into a new era. Sustainability 3:1944-1971. doi:10.3390/su3101944

Döring T, Pautasso M, Wolfe MS, Finckh MR (2012) Pest and disease management in organic farming: implications and inspirations for plant breeding. In: Lammerts van Bueren ET, Myers JR (eds.) Organic crop breeding. Wiley-Blackwell, Hoboken, pp. 39-59. ISBN 978-0-470-95858-2

Duelli P (2006) Concepts of multifunctional agriculture and functional biodiversity. In: Biala K, Paracchini ML, Terres JM, Pointereau P, Pezet J (eds) Bio-diversity serving agriculture. Institute for Environment and Sustainability, Ranco, p 44

El Bouhssini M, Ogbonnaya FC, Ketata H, Mosaad MM, Street K, Amri A, Keser M, Rajaram S, Morgounov A, Ihawi F, Dabus A, Smith CM (2011) Progress in host plant resistance in wheat to Russian wheat aphid (Hemiptera: Aphididae) in North Africa and West Asia. Aust J Crop Sci 5:1108-1113

Enjalbert J, Dawson JC, Paillard S, Rhoné B, Rousselle Y, Thomas M, Goldringer I (2011) Dynamic management of crop diversity: from an experimental approach to on-farm conservation. Comptes Rendues Biologies 334:458-468. doi:10.1016/j.crvi.2011.03.005

Fabre F, Rousseau E, Mailleret L, Moury B (2012) Durable strategies to deploy plant resistance in agricultural landscapes. New Phytol 193: 1064-1075. doi:10.1111/j.1469-8137.2011.04019.x

Finckh MR (2008) Integration of breeding and technology into diversification strategies for disease control in modern agriculture. Eur J Plant Pathol 121:299-409. doi:10.1007/s10658-008-9273-6

Finckh MR, Gacek ES, Czembor HJ, Wolfe MS (1999) Host frequency and density effects on powdery mildew and yield in mixtures of barley cultivars. Plant Pathol 48:807-816. doi:10.1046/j.1365-3059. 1999.00398.x

Finckh MR, Gacek ES, Goyeau H, Lannou C, Merz U, Mundt CC, Munk L, Nadziak J, Newton AC, De Vallavielle-Pope C, Wolfe MS (2000) Cereal variety and species mixture in practice, with special emphasis on disease resistance. Agronomie 20:813-837

Foletto B (2008) European rules for registration of varieties on a national catalogue (and a recommended variety list) for cereals. In: Rey F, Fontaine L, Osman A, van Waes J (eds.) Proceedings of the COST ACTION 860-ISUSVAR and ECO-PB Workshop on Value for Cultivation and Use testing of organic cereal varieties. What are the key issues? 28th and 29th February 2008, Brussels, Belgium. SUSVAR, COST, ECO-PB, ITAB, Paris, France, pp. 9-10 (full proceedings available at www.eco-pb.org)

Fornara DA, Tilman D (2008) Plant functional composition influences rates of soil carbon and nitrogen accumulation. J Ecol 96:314-322. doi:10.1111/j.1365-2745.2007.01345.x

Fornara DA, Tilman D (2009) Ecological mechanisms associated with the positive diversity-productivity relationship in an $\mathrm{N}$ limited grassland. Ecol 90:408-418. doi:10.1890/08-0325.1

Foulkes MJ, Hawkesford MJ, Barraclough PB, Holdsworth MJ, Kerr S, Kightley S, Shewry PR (2009) Identifying traits to improve the nitrogen economy of wheat. Field Crops Res 114:329-342. doi:10. 1016/j.fcr.2009.09.005

Foulkes MJ, Slafer GA, Davies WJ, Berry PM, Sylvester-Bradley R, Martre P, Calderini DF, Griffith S, Reynolds MP (2011) Raising yield potential of wheat III. Optimizing partitioning to grain while maintaining lodging resistance. J Exp Bot 62:469-486. doi:10.1093/jxb/erq300

Fridley JD, Grime JP (2010) Community and ecosystem effects of intraspecific genetic diversity in grassland microcosm of varying species diversity. Ecology 91:2272-2283. doi:10.1890/09-1240.1

Fridley JD, Grime JP, Bilton M (2007) Genetic identity of interspecific neighbours mediates plant responses to competition and environmental variation in a species-rich grassland. J Ecol 95:908-915. doi:10.1111/j. 1365-2745.2007.01256.x

Fukai S, Midmore DJ (1993) Adaptive research for intercropping: steps towards the transfer of intercrop research findings to farmers' fields. Filed Crops Res 34:459-467. doi:10.1016/0378-4290(93)90126-8

Garret KA, Hulbert SH, Leach JE, Travers SE (2006) Ecological genomics and epidemiology. Eur J Plant Pathol 115:35-51. doi:10.1007/ s10658-005-4050-2

Garret KA, Zúñiga LN, Roncal E, Forbes GA, Mundt CC, Su Z, Nelson RJ (2009) Intraspecific functional diversity in hosts and its effect on disease risk across a climatic gradient. Ecol App 19:1868-1883. doi: 10.1890/08-0942.1

Giampietro M (2004) Multi-scale integrated analysis of agroecosystems. CRC, Boca Raton, p. 73

Glen DM (2000) The effects of cultural measures on cereal pests and their role in integrated pest management. Integr Pest Manag Rev 5:25-40. doi:10.1023/A:1009609504464

Goldringer I, Paillard S, Enjalbert J, David JL, Brabant P (1998) Divergent evolution of wheat populations conducted under recurrent selection and dynamic management. Agronomie 18:413-425. doi: 10.1051/agro:19980506

Goldringer I, Prouin C, Rousset M, Galic N, Bonnin I (2006) Rapid differentiation of experimental populations of wheat for heading time in response to local climatic conditions. Ann Bot 98:805817. doi:10.1093/aob/mcl160

Grime JP (1998) Benefits of plant diversity to ecosystems: immediate, filter and founder effects. J Ecol 86:902-910. doi:10.1046/j.13652745.1998.00306.x

Guarda G, Padovan S, Delogu G (2004) Grain yield, nitrogen-use efficiency and baking quality of old and modern Italian bread-wheat cultivars grown at different nitrogen levels. Eur J Agron 21:181192. doi:10.1016/j.eja.2003.08.001

Hartwig NL, Ammon HU (2002) Cover crops and living mulches. Weed Sci 50:688-699. doi:10.1614/0043-1745(2002)050[0688:AIACCA] 2.0. $\mathrm{CO} ; 2$

Hauggaard-Nielsen H, Ambus P, Jensen ES (2001) Interspecific competition, $\mathrm{N}$ use and interference with weeds in pea-barley intercropping. Field Crops Res 70:101-109. doi:10.1007/s10705009-9254-y

Helland SJ, Holland JB (2001) Blend response and stability and cultivar blending ability in oat. Crop Sci 41:1689-1696

Hensleigh PF, Blake TK, Welty LE (1992) Natural selection on winter barley composite cross XXVI affects winter survival and associated traits. Crop Sci 32:57-62. doi:10.2135/cropsci1992.0011183X003200010013x

Hill J (1996) Breeding components for mixture performance. Euphytica 92:135-138. doi:10.1007/BF00022838

Hiltbrunner J, Liedgens M (2008) Performance of winter wheat varieties in white clover living mulch. Biol Agric Hortic 26:85-101. doi:10. 1080/01448765.2008.9755071

Hiltbrunner J, Liedgens M, Bloch L, Stamp P, Streit B (2007a) Legume cover crops as living mulches for winter wheat: components of biomass and the control of weeds. Eur J Agron 26:21-29. doi:10. 1016/j.eja.2006.08.002

Hiltbrunner J, Jeanneret P, Liedgens M, Stamp P, Streit B (2007b) Response of weed communities to legume living mulches in winter wheat. J Agron Crop Sci 193:93-102. doi:10.1111/j.1439-037X. 2007.00250.x

Hiltbrunner J, Streit B, Liedgens M (2007c) Are seeding densities an opportunity to increase grain yield of winter wheat in a living mulch of white clover? Field Crops Res 102:163-171. doi:10.1016/j.fcr. 2007.03.009

Hoad SP, Bertholdsson NØ, Neuhoff D, Köpke U (2012) Approaches to breed for improved weed suppression in organically grown cereals. In: Lammerts van Bueren ET, Myers JR (eds.) Organic crop breeding. Wiley-Blackwell, Hoboken, pp. 61-76. ISBN 978-0-47095858-2 
Hoisington D, Khairallah M, Reeves T, Ribaut JM, Skovmand B, Taba S, Warburton M (1999) Plant genetic resources: what can they contribute toward increased crop productivity? Proc Natl Acad Sci U S A 96:5937-5943. doi:10.1073/pnas.96.11.5937

Hollomon DW, Brent KJ (2009) Combating plant diseases - the Darwin connection. Pest Manag Sci 65:1156-1163. doi:10.1002/ps.1845

Howard PH (2009) Visualizing consolidation in the global seed industry: 1996-2008. Sustainability 1:1266-1287. doi:10.3390/su1041266

Huel DG, Hucl P (1996) Genotypic variation for competitive ability in spring wheat. Plant Breed 115:325-329. doi:10.1111/j.1439-0523. 1996.tb00927.x

Ibrahim KM, Hayter JBR, Barret JA (1996) Frequency changes in storage protein genes in a hybrid bulk population of barley. Heredity 77 : 231-239. doi:10.1038/sj.hdy.6880440

Isidro J, Álvaro F, Royo C, Villegas D, Miralles DJ, García Del Moral LF (2011) Changes in duration of developmental phases of durum wheat caused by breeding in Spain and Italy during the 20th century and its impact on yield. Ann Bot 107:1355-1366. doi:10.1093/aob/ mer063

Jackson L, van Noordwijk M, Bengtsson J, Foster W, Lipper L, Pulleman M, Said M, Snaddon J, Vodouhe R (2010) Biodiversity and agricultural sustainability: from assessment to adaptive management. Curr Opin Environ Sustain 2:80-87. doi:10.1016/j.cosust.2010.02.007

Jaggard KW, Qi A, Ober ES (2010) Possible changes to arable crop yields by 2050. Phil Trans R Soc B 365:2835-2851. doi:10.1098/rtsb. 2010.0153

Jana MK, Jana S, Acharya SN (1980) Salt stress tolerance in heterogeneous population of barley. Euphytica 29:409-417. doi:10.1007/ BF00025140

Jensen ES (1996) Grain yield, symbiotic N2 fixation and interspecific competition for inorganic N in pea-barley intercrops. Plant Soil 182: 25-38. doi:10.1007/BF00010992

Johansen A, Jensen ES (1996) Transfer of N and P from intact or decomposing roots of pea to barley interconnected by an arbuscular mycorrhizal fungus. Soil Biol Biochem 28:73-81. doi:10.1016/ 0038-0717(95)00117-4

Jones H, Jarman RJ, Austin L, White J, Cooke RJ (2003) The management of variety reference collections in distinctness, uniformity and stability testing of wheat. Euphytica 132:175-184. doi:10.1023/ A: 1024642828705

Jordan N (1993) Prospects for weed control through crop interference. Ecol Appl 3:84-91. doi:10.2307/1941794

Juskiw PE, Helm JH, Salmon DF (2000) Competitive ability in mixtures of small grain cereals. Crop Sci 40:159-164. doi:10.2135/ cropsci2000.401159x

Kairudin NMD (1991) Productivity of homogeneous and heterogeneous oat populations at two sowing dates. Pertanika 14(3):229-236

Kaut AHEE, Mason HE, Navabi A, O’Donovan JT, Spaner D (2009) Performance and adaptability of performance of spring wheat variety mixtures in organic and conventional management systems in western Canada. J Agric Sci 147:141-153. doi:10.1017/ S0021859608008319

Khalifa MA, Qualset CO (1974) Intergenotypic competition between tall and dwarf wheats. I. In mechanical mixtures. Crop Sci 14:795-799

Khalifa MA, Qualset CO (1975) Intergenotypic competition between tall and dwarf wheats. II. In hybrid bulks. Crop Sci 15:640-644

Kiær LP, Skovgaaed IM, Østergård H (2009) Grain yield increase in cereal variety mixtures: a meta-analysis of field trials. Field Crops Res 114:361-373. doi:10.1016/j.fcr.2009.09.006

Kiær LP, Skovgaaed IM, Østergård H (2012) Effects of inter-varietal diversity, biotic stresses and environmental productivity on grain yield of spring barley variety mixtures. Euphytica 185:123-138. doi: 10.1007/s10681-012-0640-1

Kilpatrick RA (1975) New wheat cultivars and longevity of rust resistance 1971-1975. U.S. Agricultural Research Service North-East Region. ARS-NE NE-64
Kirkegaard J, Christen O, Krupinsky J, Layzell D (2008) Break crop benefits in temperate wheat production. Field Crops Res 107:185195. doi:10.1016/j.fcr.2008.02.010

Knapp S, Snape J, Döring TF, Wolfe MS, Griffiths S (2013) Genetic analysis of evolving winter wheat populations reveals reversion to wild type. Döring T, Howlett S, Winkler L, Wolfe MS (eds.) Proceedings of the International Symposium on Evolutionary Breeding in Cereals, Aston University, Birmingham (UK), 21 January 2013. The Organic Research Centre, Hamstead Marshall, UK, p. 9 (full proceedings available at http://orgprints.org/ 22440/)

Kou Y, Wang S (2010) Broad-spectrum and durability: understanding of quantitative disease resistance. Curr Opin Plant Biol 13:181-185. doi:10.1016/j.pbi.2009.12.010

Lammerts van Bueren ET, Backes G, de Vriend H, Østergård H (2010) The role of molecular markers and marker assisted selection in breeding for organic agriculture. Euphytica 175:51-64. doi:10.1007/s10681-010-0169-0

Lammerts van Bueren ET, Jones SS, Tamm L, Murphy KM, Myers JR, Leifert C, Messmer MM (2011) The need to breed crop varieties suitable for organic farming, using wheat, tomato and broccoli as examples: a review. NJAS - Wageningen J Life Sci 58:193-205. doi:10.1016/j.njas.2010.04.001

Lannou C, Mundt CC (1996) Evolution of a pathogen population in host mixtures: simple race-complex race competition. Plant Pathol 45: 440-453. doi:10.1046/j.1365-3059.1996.d01-138.x

Lannou C, Mundt CC (1997) Evolution of a pathogen in host mixtures: rate of emergence of complex races. Theor Appl Genet 94:991-999. doi:10.1007/s001220050506

Laperche A, Brancourt-Hulmel M, Heumez E, Gardet O, Hanocq E, Devienne-Barret F, Le Gouis J (2007) Using genotype x nitrogen interaction variables to evaluate QTL involved in wheat tolerance to nitrogen constraints. Theor Appl Genet 115:399-415. doi:10.1007/ s00122-007-0575-4

Lee KM, Shroyer JP, Herrman TJ, Lingenfelser J (2006) Blending hard white wheat to improve grain yield and end-use performances. Crop Sci 46:1124-129. doi:10.2135/cropsci2005.07-0184

Lemerle D, Verbeek B, Orchard B (2001) Ranking the ability of wheat varieties to compete with Lolium rigidum. Weed Res 41:197-209. doi:10.1046/j.1365-3180.2001.00232.x

Li H, Shen J, Zhang F, Clairotte M, Drevon JJ, Le Cadre E, Hinsinger P (2008) Dynamics of phosphorus fractions in the rhizosphere of common bean (Phaseolus vulgaris L.) and durum wheat (Triticum turgidum durum L.) grown in monocropping and intercropping systems. Plant Soil 312:139-150. doi:10.1007/s11104-007-9512-1

Liebman M, Dyck E (1993) Crop rotation and intercropping strategies for weed management. Ecol Appl 3:92-122. doi:10.2307/1941795

Lithourgidis AS, Dordas CA (2010) Forage yield, growth rate, and nitrogen uptake of faba bean intercrops with wheat, barley, and rye in three seeding ratios. Crop Sci 50:2148-2158. doi:10.2135/ cropsci2009.12.0735

Lithourgidis AS, Dhima KV, Vasilakoglou IB, Dordas CA, Yiakoulaki MD (2007) Sustainable production of barley and wheat by intercropping common vetch. Agron Sust Dev 27:95-99. doi:10. 1051/agro:2006033

Lithourgidis AS, Dordas CA, Damalas CA, Vlachostergios DN (2011a) Annual intercrops: an alternative pathway for sustainable agriculture. Austr J Crop Sci 5:396-410

Lithourgidis AS, Vlachostergios DN, Dordas CA, Damalas CA (2011b) Dry matter yield, nitrogen content, and competition in pea-cereal intercropping systems. Eur J Agron 34:287-294. doi:10.1016/j.eja. 2011.02.007

Lopez CG, Mundt CC (2000) Using mixing ability analysis from twoway cultivar mixtures to predict the performance of cultivars in complex mixtures. Field Crop Res 68:121-132. doi:10.1016/ S0378-4290(00)00114-3 
Mäder P, Fließbach A, Dubois D, Gunst L, Fried P, Niggli U (2002) Soil fertility and biodiversity in organic farming. Science 296:1694 1697. doi:10.1126/science. 1071148

Malézieux E (2012) Designing cropping systems from nature. Agron Sust Dev 32:15-29. doi:10.1007/s13593-011-0027-z

Malézieux E, Crozat Y, Dupraz C, Laurans M, Makowski D, Ozier-Lafontaine H, Rapidel B, De Tourdonnet S, Valantin-Morison M (2009) Mixing plant species in cropping systems: concepts, tools and models. A review. Agron Sust Dev 29:43-62. doi:10.1051/agro:2007057

Marshall DR (1977) The advantages and hazards of genetic homogeneity. Ann N Y Acad Sci 287:1-20. doi:10.1111/j.1749-6632.1977. tb34226.X

Marshall DR (1991) Alternative approaches and perspectives in breeding for higher yields. Field Crops Res 26:171-190. doi:10.1016/03784290(91)90034-S

Marten GG (1988) Productivity, stability, sustainability, equitability and autonomy as properties for agroecosystem assessment. Agric Sys 26:291-316. doi:10.1016/0308-521X(88)90046-7

McIntosh RA (1998) Breeding wheat for resistance to biotic stresses. Euphytica 100:19-34. doi:10.1023/A:1018387402918

Mengistu N, Baenziger PS, Nelson LA, Eskridge KM, Klein RN, Baltensperger DD, Elmore W (2010) Grain yield performance and stability of cultivar blends vs component cultivars of hard winter wheat in Nebraska. Crop Sci 50:617-623. doi:10.2135/cropsci2009.05.0280

Messmer M, Hildermann I, Thorup-Kristensen K, Rengel Z (2012) Nutrient management in organic farming and consequences for direct and indirect selection strategies. In: Lammerts van Bueren ET, Myers JR (eds.) Organic crop breeding. Wiley-Blackwell, Hoboken, pp. 15-38. ISBN 978-0-470-95858-2

Midmore DJ (1993) Agronomic modification of resource use and intercrop productivity. Field Crops Res 34:357-380. doi:10.1016/03784290(93)90122-4

Miedaner T, Wilde F, Korzun V, Ebmeyer E, Schmolke M, Hartl L, Schön C (2009) Marker selection for Fusarium head blight resistance based on quantitative trait loci (QTL) from two European sources compared to phenotypic selection in winter wheat. Euphytica 166:219 227. doi:10.1007/s10681-008-9832-0

Milach SCK, Federizzi LC (2001) Dwarfing genes in plant improvement. Adv Agron 73:35-63. doi:10.1016/S0065-2113(01)73004-0

Mille B, Belhaj Fraj M, Monod H, De Vallavieille-Pope C (2006) Assessing four-way mixtures of winter wheat cultivars from the performances of their two-way and individual components. Eur J Plant Pathol 114:163-173. doi:10.1007/s10658-005-4036-0

Millennium Ecosystem Assessment (2003) Ecosystems and human wellbeing: a framework for assessment. Island, Washington DC, pp 53-61

Mokany K, Ash J, Roxburh S (2008) Functional identity is more important than diversity in influencing ecosystem processes in a temperate grassland. J Ecol 96:884-893. doi:10.1111/j.1365-2745.2008.01395.x

Moonen AC, Bàrberi P (2008) Functional biodiversity: an agroecosystem approach. Agric Ecosys Environ 127:7-21. doi:10.1016/j.agee. 2008.02.013

Morris RA, Garrity DP (1993a) Resource capture and utilization in intercropping: non-nitrogen nutrients. Field Crops Res 34:319334. doi:10.1016/0378-4290(93)90120-C

Morris RA, Garrity DP (1993b) Resource capture and utilization in intercropping: water. Field Crop Res 34:303-317. doi:10.1016/ 0378-4290(93)90119-8

Motzo R, Giunta F, Pruneddu G (2007) The response of rate and duration of grain filling to long-term selection for yield in Italian durum wheats. Crop and Pasture Science 61:162-169. doi:10.1071/CP09191

Mueller ND, Gerber JS, Johnston M, Ray DK, Ramankutty N, Foley JA (2012) Closing yield gaps through nutrient and water management. Nature 490:254-257. doi:10.1038/nature 11420

Mundt CC (2002a) Performance of wheat cultivars and cultivar mixtures in the presence of Cephalosporium stripe. Crop Prot 21:93-99. doi: 10.1016/S0261-2194(01)00067-9
Mundt CC (2002b) Use of multiline cultivars and cultivar mixtures for disease management. Annu Rev Plant Physiol Plant Mol Biol 40: 381-410. doi:10.1146/annurev.phyto.40.011402.113723

Mundt CC, Cowger C, Garret KA (2002) Relevance of integrated disease management to resistance durability. Euphytica 124:245-252. doi: 10.1023/A:1015642819151

Murphy JP, Helsel DB, Elliot A, Thro AM, Frey KJ (1982) Compositional stability of an oat multiline. Euphytica 31:33-40. doi:10.1007/BF00028304

Murphy KM, Campbell KG, Lyon SR, Jones SS (2007) Evidence of varietal adaptation to organic farming systems. Field Crops Res 102: 172-177. doi:10.1016/j.fcr.2007.03.011

Murphy KM, Dawson JC, Jones SS (2008) Relationship between yield and mineral nutrient concentrations in historical and modern spring wheat cultivars. Field Crops Res 105:107-115. doi:10.1016/j.fcr.2007.08.004

Nevo E, Chen G (2010) Drought and salt tolerance in wild relatives for wheat and barley improvement. Plant Cell Envir 33:670-685. doi: 10.1111/j.1365-3040.2009.02107.x

Newton AC, Guy DC (2009) The effect of uneven, patchy cultivar mixture on disease control and yield in winter barley. Field Crops Res 110:225-228. doi:10.1016/j.fcr.2008.09.002

Newton AC, Begg GS, Swantson JS (2009) Deployment of diversity for enhanced crop function. Ann Appl Biol 154:309-322. doi:10.1111/ j.1744-7348.2008.00303.x

Newton AC, Akar T, Baresel JP, Bebeli PJ, Bettencourt E, Bladenopoulos KV, Czembor JH, Fasoula DA, Katsiotis A, Koutis K, KoutsikaSotirou M, Kovacs G, Larsson H, De Carvalho MAAP, Rubiales D, Russel J, Dos Santos TMM, Vaz Patto MC (2010) Cereal landraces for sustainable agriculture. Agron Sust Dev 30:237-269. doi:10. 1051/agro/2009032

Olesen JE, Hansen PK, Berntsen J, Christensen S (2004) Simulation of above-ground suppression of competing species and competition tolerance in winter wheat varieties. Field Crops Res 89:263-280. doi:10.1016/j.fcr.2004.02.005

Olesen JE, Askegaard M, Rasmussen IA (2009) Winter cereal yield as affected by animal manure and green manure in organic arable fields. Eur J Agron 30:119-128. doi:10.1016/j.eja.2008.08.002

Olesen JE, Trnka M, Kersebaum KC, Skjelvåg AO, Seguin B, PeltonenSainio P, Rossi F, Kozyra J, Micale F (2011) Impacts and adaptation of European crop production systems to climate change. Eur J Agron 34:96-112. doi:10.1016/j.eja.2010.11.003

Olivera PD, Steffenson BJ (2009) Aegilops sharonensis: origin, genetics, diversity and potential for wheat improvement. Botany 87:740-756. doi:10.1139/B09-040

Osman A, van den Brink L, Lammerts van Bueren E (2008) Comparing organic and conventional VCU testing for winter wheat in the Netherlands. In: Rey F, Fontaine L, Osman A, van Waes J (eds.) Proceedings of the COST ACTION 860-SUSVAR and ECO-PB Workshop on Value for Cultivation and Use testing of organic cereal varieties. What are the key issues? 28th and 29th February 2008, Brussels, Belgium. SUSVAR, COST, ECO-PB, ITAB, Paris, France, pp. 37-40 (full proceedings available at http://ecopb.org)

Pang XP, Letey J (2000) Organic farming: challenge of timing nitrogen availability to crop nitrogen requirements. Soil Sci Soc Am J 64: 247-253. doi:10.2136/sssaj2000.641247x

Papaix J, Goyeau H, Du Cheyron P, Monod H, Lannou C (2011) Influence of cultivated landscape composition on variety resistance: an assessment based on wheat leaf rust epidemics. New Phytol 191: 1095-1107. doi:10.1111/j.1469-8137.2011.03764.x

Parris K (2001) OECD agri-biodiversity indicators: background paper. In Agriculture and biodiversity: developing indicators for policy analysis. Proceedings from an OECD expert meeting, Zurich, Switzerland, November 2001, pp. 27-39

Parry MAJ, Reynolds M, Salvucci ME, Raines C, Andralojc PJ, Zhu XG, Price GD, Condon AG, Furbank RT (2010) Raising yield potential 
of wheat. II. Increasing photosynthetic capacity and efficiency. J Exp Bot 62:453-467. doi:10.1093/jxb/erq304

Pereira MG, De Oliveira LO, Lee M (2000) QTL mapping and disease resistance in cereals. J New Seeds 2:1-21. doi:10.1300/J153v02n02_01

Phillips SL, Wolfe MS (2005) Evolutionary plant breeding for low input systems. J Agric Sci 143:245-254. doi:10.1017/S0021859605005009

Piepho HP (1998) Methods for comparing the yield stability of cropping systems - a review. J Agron Crop Sci 180:193-213. doi:10.1111/j. 1439-037X.1998.tb00526.x

Poggio S (2005) Structure of weed communities occurring in monoculture and intercropping of field pea and barley. Agric Ecosys Environ 109:48-58. doi:10.1016/j.agee.2005.02.019

Pollnac FW, Maxwell BD, Menalled FD (2009) Weed community characteristics and crop performance: a neighbourhood approach. Weed Res 49:242-250. doi:10.1111/j.1365-3180.2009.00688.x

Powell N, Ji X, Ravash R, Edlington J, Dolferus R (2012) Yield stability for cereals in a changing climate. Funct Plant Biol 39:539-552. doi: 10.1071/FP12078

Praba ML, Cairns JE, Babu RC, Lafitte HR (2009) Identification of physiological traits underlying cultivar differences in drought tolerance in rice and wheat. J Agron Crop Sci 195:30-46. doi:10.1111/j. 1439-037X.2008.00341.x

Prato T (2008) Accounting for risk and uncertainty in determining preferred strategies for adapting to future climate change. Mitig Adapt Strat Glob Change 13:47-60. doi:10.1007/s11027-007-9080-y

Ransom JK, Endres GJ, Schatz BG (2007) Sustainable improvement of wheat yield potential: the role of crop management. J Agric Sci 145: 55-61. doi:10.1017/S002185960600668X

Rasmussen IA (2004) The effect of sowing date, stale seedbed, row width and mechanical weed control on weeds and yields of organic winter wheat. Weed Res 44:12-20. doi:10.1046/j.1365-3180.2003.00367.x

Rasmusson DC (1991) A plant breeder's experience with ideotype breeding. Field Crops Res 26:191-200. doi:10.1016/0378-4290(91)90035-T

Ratnadass A, Fernandes P, Avelino J, Habib R (2012) Plant species diversity for sustainable management of crop pests and diseases in agroecosystems: a review. Agron Sust Dev 32:273-303. doi:10. 1007/s13593-011-0022-4

Raun WR, Johnson GV (1999) Improving nitrogen use efficiency for cereal production. Agron J 91:357-363

Reidsma P, Ewert F, Lansink AO, Leemans R (2010) Adaptation to climate change and climate variability in Europe: the importance of farm level responses. Eur J Agron 32:91-102. doi:10.1016/j.eja. 2009.06.003

Reis EM, Casa RT, Bianchin V (2011) Control of plant disease by crop rotation. Summa Phytopathol 37:85-91. doi:10.1590/S010054052011000300001

Reynolds M, Foulkes MJ, Slafer GA, Berry P, Parry MAJ, Snape JW, Angus WJ (2009) Raising yield potential in wheat. J Exp Bot 60: 1899-1918. doi:10.1093/jxb/erp016

Rhoné B, Vitalis R, Goldringer I, Bonnin I (2010) Evolution of flowering time in experimental wheat populations: a comprehensive approach to detect genetic signatures of natural selection. Evolution; Int J Org Evol 64:2110-2125. doi:10.1111/j.1558-5646.2010.00970.x

Schmidt O, Curry JP (1999) Effects of earthworms on biomass production, nitrogen allocation and nitrogen transfer in wheat-clover intercropping model systems. Plant Soil 214:187-198. doi:10. 1023/A:1004723914623

Schmidt O, Clements RO, Donaldson G (2003) Why do cereal-legume intercrops support large earthworms populations? Appl Soil Ecol 22:181-190. doi:10.1016/S0929-1393(02)00131-2

Sedgley RH (1991) An appraisal of the Donald ideotype after 21 years. Field Crops Res 26:93-112. doi:10.1016/0378-4290(91)90031-P

Shavrukov Y, Langridge P, Tester M, Nevo E (2010) Wide genetic diversity of salinity tolerance, sodium exclusion and growth in wild emmer wheat, Triticum dicoccoides. Breeding Sci 60:426-435. doi: $10.1270 /$ jsbbs. 60.426
Siahpoosh MR, Dehghanian E, Kamgar A (2011) Drought tolerance evaluation of bread wheat genotypes using water use efficiency, evapotranspiration efficiency and drought susceptibility index. Crop Sci 51:1198-1204. doi:10.2135/cropsci2010.05.0243

Singer JW, Casler MD, Kohler KA (2006) Wheat effect on frost-seeded red clover cultivar establishment and yield. Agron J 98:265-269. doi:10.2134/agronj2005.003

Stagnari F, Onofri A, Codianni P, Pisante M (2013) Durum wheat varieties in $\mathrm{N}$-deficient environments and organic farming: a comparison of yield, quality and stability performances. Plant Breed 132:266-275. doi:10.1111/pbr.12044

Stern WR (1993) Nitrogen fixation and transfer in intercrop systems. Field Crops Res 34:335-356. doi:10.1016/0378-4290(93)90121-3

Stützel H, Aufhammer W (1990) The physiological causes of mixing effects in cultivar mixtures: a general hypothesis. Agric Sys 32:4153. doi:10.1016/0308-521X(90)90029-P

Suneson CA (1956) An evolutionary plant breeding method. Agron J 48: 188-191. doi:10.2134/agronj1956.00021962004800040012x

Sylvester-Bradley R, Kindred DR (2009) Analysing nitrogen responses of cereals to prioritize routes to the improvement of nitrogen use efficiency. J Exp Bot 60:1939-1951. doi:10.1093/jxb/erp116

Thapa R, Carver BF, Horn GW, Goad CL (2010) Genetic differentiation of winter wheat populations following exposure to two management systems in early inbreeding generations. Crop Sci 50:591-601. doi: 10.2135/cropsci2009.05.0234

Thorsted MD, Olesen JE, Weiner J (2006a) Width of clover strips and wheat rows influence grain yield in winter wheat in winter wheat/ white clover intercropping. Field Crops Res 95:280-290. doi:10. 1016/j.fcr.2005.04.001

Thorsted MD, Olesen JE, Weiner J (2006b) Mechanical control of clover improves nitrogen supply and growth of wheat in winter wheat/ white clover intercropping. Eur J of Agron 24:149-155. doi:10. 1016/j.eja.2005.07.004

Thorup-Kristensen K, Majid J, Jensen LS (2003) Catch crops and green manures as biological tools in nitrogen management in temperate zones. Adv Agron 79:227-302. doi:10.1016/S0065-2113(02) 79005-6

Thorup-Kristensen K, Salmerón Cortasa M, Loges R (2009) Winter wheat roots grow twice as deep as spring wheat roots, is this important for $\mathrm{N}$ uptake and $\mathrm{N}$ leaching losses? Plant Soil 322: 101-114. doi:10.1006/s11104-009-9898-Z

Tilman D, Knops J, Wedin D, Recih P, Ritchie M, Siemann E (1997) The influence of functional diversity and composition on ecosystem processes. Science 277:1300-1302. doi:10.1126/science.277.5330.1300

Tooker JF, Frank SD (2012) Genotypically diverse cultivar mixtures for insect pest management and increased crop yields. J Appl Ecol 49: 974-985. doi:10.1111/j.1365-2664.2012.02173.x

Tosti G, Guiducci M (2010) Durum wheat-faba bean temporary intercropping: effects on nitrogen supply and wheat quality. Eur J Agron 33:157-165. doi:10.1016/j.eja.2010.05.001

Trenbath BR (1993) Intercropping for the management of pests and diseases. Field Crops Res 34:381-405. doi:10.1016/03784290(93)90123-5

Trethowan RM, Mujeeb-Kazi A (2008) Novel germplasm resources for improving environmental stress tolerance of hexaploid wheat. Crop Sci 48:1255-1265. doi:10.2135/cropsci2007.08.0477

Tsubo M, Walker S, Mukhala E (2001) Comparisons of radiation use efficiency of mono-/intercropping systems with different row orientation. Field Crops Res 71:17-29. doi:10.1016/S0378-4290(01)00142-3

Valkoun JJ (2001) Wheat pre-breeding using wild progenitors. Euphytica 119:17-23. doi:10.1023/A:1017562909881

Vandermeer J, Lawrence D, Symstad A, Hobbie S (2002) Effect of biodiversity on ecosystem functioning in managed ecosystems. In: Loreau M, Naeem S, Inchausti P (eds.) Biodiversity and ecosystem functioning: synthesis and perspectives. Oxford University Press, London, pp. 221-242. 
Vasilakoglou I, Dhima K, Lithourgidis AS, Eleftherohorinos I (2008) Competitive ability of winter cereal-common vetch intercrops against sterile oat. Exp Agric 44:509-520. doi:10.1017/S0014479708006728

Vera CL, Hox SL, DePauw RM, Smith MAH, Wise IL, Clarke FR, Procunier JD, Lukow OM (2013) Relative performance of resistant wheat varietal blends and susceptible cultivars exposed to wheat midge, Sitodiplosis mosellana (Géhin). Can J Plant Sci 93(1):59 66. doi: 10.4141/cjps2012-019

Wetterich F (2001) Biological diversity of livestock and crops: useful classification and appropriate agri-environmental indicators. In Agriculture and biodiversity: developing indicators for policy analysis. Proceedings from an OECD expert meeting, Zurich, Switzerland, November 2001, pp. 40-55

Wezel A, Bellon S, Doré T, Francis C, Vallod D, David C (2009) Agroecology as a science, a movement and a practice. A review. Agron Sust Dev 29:503-515. doi:10.1051/agro/2009004

Whitlock RAJ, Grime JP, Burke T (2010) Genetic variation in plant morphology contributes to the species-level structure of grassland communities. Ecology 91:1344-1354. doi:10.1890/08-2098.1

Whitmore AP, Schröder JJ (2007) Intercropping reduces nitrate leaching from under field crops without loss of yield: a modeling study. Eur J of Agron 27:81-88. doi:10.1016/j.eja.2007.02.004

Winkler L, Howlett S, Döring T (2013) Minutes from the plenary discussion: taking evolutionary breeding into the future. In Döring $\mathrm{T}$, Howlett S, Winkler L, Wolfe MS (eds.) Proceedings of the International Symposium on Evolutionary Breeding in Cereals, Aston University, Birmingham (UK), 21 January 2013. The Organic Research Centre, Hamstead Marshall, UK, pp. 20-21 (full proceedings available at http://orgprints.org/22440/)

Witcombe JR, Hollington PA, Howarth CJ, Reader S, Steele KA (2008) Breeding for abiotic stresses for sustainable agriculture. Phylos Trans R Soc B 363:703-716. doi:10.1098/rstb.2007.2179

Woldeamlak A, Grando S, Maatougui M, Ceccarelli S (2008) Hanfets, a barley and wheat mixture in Eritrea: yield, stability and farmer preferences. Field Crops Res 109:50-56. doi:10.1016/j.fcr.2008.06.007
Wolfe MS (2000) Crop strength through diversity. Nature 406:681-682. doi: $10.1038 / 35021152$

Wolfe MS, Minchin PN, Slater SE (1987) Control of barley mildew by integrating the use of varietal resistance and seed-applied fungicides. In Cavalloro R (2000) Integrated Crop Protection in Cereals. Brussels: Commission of the European Community. pp. 229236

Wolfe MS, Hinchsliffe KE, Clarke SM, Jones H, Haigh Z (2006) Evolutionary breeding of healthy wheat: from plot to farm. Aspects of applied biology 79, what will organic farmers deliver? COR 2006, pp. 47-50

Wolfe MS, Baresel J, Desclaux D, Goldringer I, Hoad S, Kovacs G, Löschenberger F, Miedaner T, Østergård H, Lammerts van Bueren E (2008) Developments in breeding cereals for organic agriculture. Euphytica 163:323-346. doi:10.1007/s10681-008-9690-9

Wolfe MS, Jones H, Howlett S, Pearce H, Winkler L, Crowley O, Döring $\mathrm{T}$ (2013) Adaptive winter wheat populations in the UK: selected results. In: Döring T, Howlett S, Winkler L, Wolfe MS (eds.) Proceedings of the International Symposium on Evolutionary Breeding in Cereals, Aston University, Birmingham (UK), 21 January 2013. The Organic Research Centre, Hamstead Marshall, UK, p. 7 (full proceedings available at http://orgprints.org/22440/)

Xie W, Nevo E (2008) Wild emmer: genetic resources, gene mapping and potential for wheat improvement. Euphytica 164:603-614. doi:10. 1007/s10681-008-9703-8

Yapa L (1977) The Green Revolution: a diffusion model. Ann Assoc Am Geogr 67:350-359

Yapa L (1993) What are improved seeds? An epistemology of the Green Revolution. Econ Geogr 69:254-273

Zhou Y, Yu L, Zhang J, Lu Y (2008) Molecular approaches in improving the rice allelopathy. Allelopathy J 22:275-281

Zhu Y, Chen H, Fan J, Wang Y, Li Y, Chen J, Fan J, Yang S, Hu L, Leung H, Mew TW, Teng PS, Wang Z, Mundt CC (2000) Genetic diversity and disease control in rice. Nature 406:718-722. doi:10.1038/ 35021046 